\title{
Macro Energy Trends and the Future of Geothermal within the Low-Carbon Energy Portfolio.
}

Philip J. Ball

Keele University, School of Geography, Geology and the Environment, Keele University, Staffordshire, UK, ST5 5BG.

(1)

\subsection{ABSTRACT}

Exploratory analysis was conducted to understand energy diversification trends within the oil, gas and power industry and to examine whether geothermal technologies play a role in the low-carbon energy mix. Investigations were completed using the 2018 end of year financial reports for thirty-six companies. Macro-scale insights reveal a significant split between European and US-based oil and gas companies in terms of strategy which is mirrored by the power companies. Diversification into lowcarbon technologies is driving an energy convergence between the oil and gas and power sectors. Presently, the oil and gas industry is not actively investing in geothermal technologies, favoring instead solar PV, onshore/offshore wind, biomass/gas, gas to power and storage. The macro-scale analysis is coupled with, twenty, semi-structured interviews with geothermal and energy specialists. The interviews provided an insight why oil and gas companies have resisted entering the geothermal industry. In addition the interviews were organized into a Political, Economic, Social, Technological, Legal and Environmental, PESTLE analysis to understand the present-day external environment of the geothermal industry in the USA today. The combined analyses indicate that the regulatory, business and finance environment for geothermal, in the USA, is challenging. Recent geothermal innovations that increase the footprint of the geothermal industry, offering new scalable, low-carbon baseload concepts, might provide an avenue for the oil and gas industry to enter the geothermal domain, while leveraging their existing core competencies, IP, technology, assets, and workforce knowledge skills and experience.

\subsection{INTRODUCTION:}

The availability of a fossil-fuel baseload energy supply has been the foundation of the developed world. Developing nations also desire access to high-density fuels to modernize and develop their own industries and economies. With an increasing population growth projected to hit 10 billion by 2100 [1], population growth coupled with a drive for modernization of underdeveloped economies, will put significant demand on existing resources such as oil and gas, energy critical elements, 
minerals, food and clean water [2]. The natural impact of population growth coupled with the modernization of developing economies in a business as usual scenario is an unavoidable increase in Greenhouse Gas (GHG) emissions. Rising GHG emissions lead to climate change and sea-level rise, potentially causing social and economic disruption $[3,4]$. In addition, such population growth also will likely heighten the focus on energy security and sustainability especially for resource challenged countries.

Decarbonization, decentralization, democratization and digitization have become key mantra in a drive to avoid an increase in GHG emissions $[3,4]$. Recent studies in the USA have suggested that the "business as usual approach" would have dramatic financial implications on the U.S. economy, arguing that inaction could lead to $10 \%$ loss of GDP by 2100 [5]. Yet, when researching energy in the USA, the dominant reference regarding the production of electricity, is the premise that energy is cheap and plentiful. Europe, in contrast, has higher electricity prices and a heightened awareness of energy security and an aging fossil-fuel infrastructure. The USA, has significant, although, finite oil resources, and this, coupled with the Trump Administration's (2016-2020) denial of the cause and consequence of anthropogenic global warming, is driving divergence of the renewable and sustainable economy in Europe vis-à-vis that in the USA [6]. Within Europe by contrast a string of high-profile Oil and Gas $(\mathrm{O} \& \mathrm{G})$ companies, in response to Environmental Social Governance (ESG) pressures, are investing in renewables or announcing 2050 emissions targets [7]. Many carbon mitigation policies, to date, have supported the development of renewable technologies such as: wind, utility-scale solar photovoltaic (solar PV) and storage, leading to a dramatic fall in the Levelized Cost of Energy (LCOE) for these, easy to deploy, technologies [8-10]. Geothermal conversely has not received comparable benefits over the last ten years [11].

Ball [12] recently reviewed geothermal technologies concluding that the geothermal industry is diverse and multi-faceted covering a range of different environments, temperatures and uses. In summary there are the following categories:

(1) Conventional high enthalpy geothermal technologies (generally one of the three types - dry steam, flash steam, and closed-loop/binary) operating generally at temperatures above $150^{\circ} \mathrm{C}$, and as low as $125^{\circ} \mathrm{C}$ if closed-loop/binary systems are installed.

(2) Conventional low-temperature geothermal technologies. These include geothermal heat pump or Ground Source Heat Pump (GSHP) and district energy systems

(3) Unconventional geothermal technologies, otherwise known as Enhanced Geothermal Systems (EGS), operating at temperatures above $150^{\circ} \mathrm{C}$. 
(4) Advanced low-enthalpy geothermal technologies. Low enthalpy or low temperature geothermal operates in the $70-150^{\circ} \mathrm{C}$ range. Advanced low-temperature geothermal can also include both closed-loop and closed-loop conduction developments.

(5) Advanced supercritical geothermal technologies. This emerging class of geothermal operates at temperatures from $150^{\circ} \mathrm{C}$ to $500^{\circ} \mathrm{C}$. Advanced supercritical geothermal can also include both closed-loop and closed-loop conduction developments.

With the current focus on the decarbonization of the energy system and the need for a renewable baseload in order to avoid getting locked into a gas-infrastructure [13], several entities have recently suggested that the $O \& G$ industry ought to pivot into geothermal technologies. A pivot into geothermal closed-loop technologies would allow the O\&G industry to leveraging core competencies, Intellectual Property (IP), technology, assets, and workforce; while meeting carbon neutrality commitments and portfolio diversification $[14,15]$.

The aims of this paper are fourfold, firstly to understand energy diversification trends within the O\&G and power industry. Secondly, to understand whether geothermal technologies are playing a role in the evolving energy transition and their current position within energy companies low-carbon energy portfolio. Thirdly, to understand why the O\&G industry has resisted investing in geothermal technologies. And, fourthly, to understand the external operating environment of geothermal in the USA.

\subsection{METHODS}

The research presented within this paper has been conducted using an exploratory methodology [16]. The original researched aimed to examine the paradox that geothermal, a low-carbon baseload power, was described as "the forgotten renewable energy" [17]. This research aimed to understand the discrete biases and opinions within the energy industry. To do this, the research was conducted using a mixed method approach [16]. Semi-structured interviews were chosen to build an understanding of a complex problem, coupled with quantitative analysis. End of year financial and sustainability reports formed a key resource used to examine the macro-energy environment.

The initial goal for the interviews was to target between 5-25 in number to provide the minimum number of interviews to make the study meaningful [18]. Invitations were extended to 32 experts, each invited expert was assigned a code which would be used for the interview to anonymize the responses, to protect the identity of the person interviewed. For example, the first person to be invited for interview was coded as GEOTHO01. All the interview candidates were approached using 
email and Linkedln (https://www.linkedin.com/). In total, 32 formal invitations were sent out to potential candidates between October and December 2019. In total twenty semi-structured interviews were successfully completed, representing a return rate of $62.5 \%$. All twenty interviews took place between November and December 2019. Eighteen interviews were conducted using the video/telephone Zoom conferencing software (https://zoom.us/), and two interviews were conducted by phone. The eighteen recorded interviews were transcribed using Rev.com or Nvivo.com transcribing services. The transcribed interviews and notes from the telephone interviews were also entered into NVIVO software for qualitative analysis.

NVIVO is a software that enables qualitative analysis of the opinions expressed from the semistructured interviews. The interviews were designed to provide flexibility, focusing on themes, rather than a strict set of questions [16]. While there were pre-prepared questions (Appendix A), no interview was the same, the questions often varied from interview to interview depending on the candidate and the discussion.

Attempts were consciously made to try to gather views from experts across different sectors of the geothermal and energy industry. All interviews conducted were guaranteed anonymity upfront in the study. This is known as cognitive access and it is an important process in negotiating participation [16]. The process of following-up initial contact with an email and an official invitation for participation enabled the interviewee to participate in an informed consent. In addition, before recording each interview, at the beginning of the interview, a face to face request for recording was again requested with the guarantee that each interview would remain confidential, this informed consent was an important step in gaining trust of the participants.

\subsection{RESEARCH CONSTRAINTS AND LIMITATIONS}

Potential limitations of this research can stem from: (a) the design of the analysis or data collection, (b) an inadequate number interviewees, (c) the qualitative nature of the results could be ambiguous, (d) the impact of new technologies may be uncertain; and (e) the future success of geothermal industries and the perception gained can be very different according to the experts accessed.

Data relating to company activities is not always in the public domain, and therefore activities collated in this study are only that which is public and reported publically in end of year financial reports. There may be some inherent errors present in this analysis since end of year reporting is generally delayed. This study, therefore, represents a picture that is available at the time of writing. This research was 
conducted from 2018 end of year and sustainability reports, which are published in early 2019, and interviews conducted in November and December 2019

\subsection{RESULTS}

\subsection{DIVERSIFICATION TRENDS WITHIN THE OIL AND GAS AND POWER INDUSTRIES}

In order to provide a quick snapshot of trends within the Power (P), Oil and Gas (O\&G), Geothermal (G), and Emerging Renewable Power (ERP) companies, the end of year reports and sustainability reports from 2018 were analyzed (Tables 1a, 1b, 1c). In total 36 companies were analyzed. The analysis, while not concerned with the cash-value or the scale of energy produced, does help build an understanding whether companies are diversifying into low-carbon technologies.

With respect to technologies used, several macro-trends can be identified these are: (1) The dominant diversification of the studied companies is in to solar PV, onshore/offshore wind, energy storage, biomass/gas, and gas to power. (2) Hydroelectric and geothermal and heat cogeneration (waste heat) are common, the former two appear, however, to be the result of acquisition and merger, rather than exploration or development of new resources particularly in the case of the power companies. (3) There is a divergence between Europe and the USA in terms of energy diversification strategy with respect to O\&G companies, the same trend is mirrored by within the power industry. (4) SHELL, is the most diversified company of the 36 companies studied with sixteen energy technologies in their portfolio. They are closely followed by followed by Equinor, TOTAL, EDF with fifteen technologies and ENEL and ENGIE with fourteen technologies. (5) Power companies are more likely to be diversified into geothermal, hydroelectric, solar PV and wind and biomass/gas than O\&G companies. (6) O\&G companies dominate the drive towards Carbon Capture Utilization and Storage (CCUS) and hydrogen. (7) Power companies are dominantly developing battery storage, although this trend is closely followed by the major O\&G companies. (8) Power companies are dominantly in nuclear. (9) Most O\&G companies have a foothold in waste heat but not geothermal energy. (10) There was one industry that does not appear to be diversified and this is the geothermal industry, where most companies rely on one to three geothermal technologies, and they are rarely diversified beyond the thermal/geothermal domain.

\begin{tabular}{|c|c|c|c|c|c|c|c|c|c|c|c|}
\hline $\begin{array}{l}\text { Geothermal } \\
\text { Companies }\end{array}$ & Geothermal & Heat Pumps & Waste Heat & Hydroelectric & Solar PV & $\begin{array}{l}\text { Wind } \\
\text { Onshore }\end{array}$ & $\begin{array}{l}\text { Wind } \\
\text { offshore }\end{array}$ & Biomas/Gas & Biofuel & $\begin{array}{l}\text { Landfill } \\
\text { Gas }\end{array}$ & Reference \\
\hline BHE (P) & $\mathrm{x}$ & & & $\mathrm{x}$ & $\mathrm{x}$ & $\mathrm{x}$ & & $\mathrm{x}$ & & & [19] \\
\hline CALPINE (P) & $\mathrm{x}$ & & & & & & & & & & [20] \\
\hline
\end{tabular}




\begin{tabular}{|c|c|c|c|c|c|c|c|c|c|c|c|}
\hline CLEAG (G) & $x$ & & & & & & & & & & [21] \\
\hline CLIMEON (G) & $x$ & & $x$ & & & & & & & & [22] \\
\hline EAVOR (G) & $x$ & & & & & & & & & & [23] \\
\hline GreenFire (G) & $x$ & & & & & & & & & & [24] \\
\hline Innergex (ERP) & $x$ & & & $x$ & $x$ & $x$ & & & & & [25] \\
\hline J-Power (P) & $\mathrm{x}$ & & & $x$ & & $x$ & & & & & [26] \\
\hline KenGen (P) & $\mathrm{x}$ & & $x$ & $x$ & $\mathrm{x}$ & $x$ & & & & & [27] \\
\hline ORMAT (G) & $x$ & & $x$ & & $x$ & & & & & & [28] \\
\hline Razor (O\&G) & $\mathrm{x}$ & & & & & & & & & & {$[29]$} \\
\hline Terra-Gen (P) & $x$ & & & & $x$ & $x$ & & & & & [30] \\
\hline $\begin{array}{c}\text { Power } \\
\text { Companies }\end{array}$ & Geothermal & Heat Pumps & Waste Heat & Hydroelectric & Solar PV & $\begin{array}{c}\text { Wind } \\
\text { Onshore }\end{array}$ & $\begin{array}{l}\text { Wind } \\
\text { Offshore }\end{array}$ & Biomas/Gas & Biofuel & Land Gas & Reference \\
\hline $\begin{array}{c}\text { Dominion } \\
\text { Resources (P) }\end{array}$ & & & & $x$ & $x$ & $x$ & $x$ & $\mathrm{x}$ & & & [31] \\
\hline Duke Energy (P) & & & & $\mathrm{x}$ & $\mathrm{x}$ & $\mathrm{x}$ & & & & & [32] \\
\hline EDF (P) & $x$ & $\mathrm{x}$ & $\mathrm{x}$ & $x$ & $x$ & $x$ & $x$ & $x$ & & & [33] \\
\hline ENEL (P) & $\mathrm{x}$ & & $\mathrm{x}$ & $x$ & $\mathrm{x}$ & $x$ & & $\mathrm{x}$ & & $\mathrm{x}$ & [34] \\
\hline ENGIE (ERP) & $x$ & $\mathrm{x}$ & & $\mathrm{x}$ & $\mathrm{x}$ & $x$ & $x$ & $x$ & & & [35] \\
\hline ELEXON (P) & & & & $x$ & $\mathrm{x}$ & $x$ & & $x$ & & $x$ & [36] \\
\hline IBERDROLA (P) & & & $\mathrm{x}$ & $x$ & $x$ & $x$ & $\mathrm{x}$ & $x$ & & & [37] \\
\hline $\begin{array}{c}\text { National Grid } \\
\text { (P) }\end{array}$ & & & & & $\mathrm{x}$ & $x$ & $x$ & & & & [38] \\
\hline NEXTERA (P) & & & & & $\mathrm{x}$ & $x$ & & & & & [39] \\
\hline $\begin{array}{c}\text { Southern } \\
\text { Company (P) }\end{array}$ & & & & $x$ & $\mathrm{x}$ & $\mathrm{x}$ & & $\mathrm{x}$ & & & [40] \\
\hline EON (P) & $x$ & $x$ & $\mathrm{x}$ & & $\mathrm{x}$ & $x$ & $x$ & $\mathrm{x}$ & & & [41] \\
\hline ØRSTED (ERP) & $x$ & $x$ & $\mathrm{x}$ & & $x$ & $x$ & $x$ & $x$ & & & [42] \\
\hline $\begin{array}{c}\text { O\&G } \\
\text { Companies }\end{array}$ & Geothermal & Heat Pumps & Waste Heat & Hydroelectric & Solar PV & $\begin{array}{l}\text { Wind } \\
\text { Onshore }\end{array}$ & $\begin{array}{c}\text { Wind } \\
\text { Offshore }\end{array}$ & Biomas/Gas & Biofuel & Land Gas & Reference \\
\hline OXY (O\&G) & & & $\mathrm{x}$ & & $x$ & & & & & & [43] \\
\hline BP (O\&G) & & & & & $\mathrm{x}$ & $x$ & $x$ & $x$ & $\mathrm{x}$ & $\mathrm{x}$ & [44] \\
\hline Chevron (O\&G) & & & & & & & $x$ & & $x$ & & [45] \\
\hline CNR (O\&G) & & & $\mathrm{x}$ & & & & & & $x$ & & [46] \\
\hline $\begin{array}{c}\text { ConocoPhillips } \\
\text { (O\&G) }\end{array}$ & & & & & & & & & $x$ & & [47] \\
\hline Devon (O\&G) & & & & & & & & & & & {$[48]$} \\
\hline ENI (O\&G) & & & & $x$ & $x$ & & $x$ & $x$ & $x$ & & [49] \\
\hline Equinor (O\&G) & $x$ & & $\mathrm{x}$ & & $x$ & & $x$ & $\mathrm{x}$ & $x$ & $x$ & [50] \\
\hline SHELL (O\&G) & $x$ & & $\mathrm{x}$ & & $\mathrm{x}$ & $x$ & $x$ & $x$ & $x$ & $x$ & [51] \\
\hline Suncor (O\&G) & & & $\mathrm{x}$ & & $\mathrm{x}$ & $x$ & & & $x$ & & [52] \\
\hline TOTAL (O\&G) & & & & $x$ & $x$ & $x$ & $x$ & $x$ & $x$ & & [53] \\
\hline $\begin{array}{c}\text { ExxonMobil } \\
\text { (O\&G) }\end{array}$ & & & $x$ & & & & & & $x$ & & [54] \\
\hline Trend Analysis & Geothermal & Heat Pumps & Waste Heat & Hydroelectric & Solar PV & $\begin{array}{l}\text { Wind } \\
\text { Onshore }\end{array}$ & $\begin{array}{c}\text { Wind } \\
\text { offshore }\end{array}$ & Biomas/Gas & Biofuel & Land Gas & \\
\hline TOTAL & 18 & 4 & 14 & 14 & 24 & 21 & 13 & 15 & 10 & 5 & \\
\hline $\begin{array}{c}\text { Geothermal } \\
\text { (12) }\end{array}$ & 12 & 0 & 3 & 4 & 5 & 5 & 0 & 1 & 0 & 0 & \\
\hline Power (12) & 3 & 4 & 5 & 8 & 12 & 12 & 7 & 9 & 0 & 2 & \\
\hline O\&G (12) & 1 & 0 & 6 & 2 & 7 & 4 & 6 & 5 & 10 & 3 & \\
\hline
\end{tabular}

154 Table 1a: Industry diversification trends. Extracted from Year End shareholder and sustainability reports published in 2018, (see references). Twelve companies from Geothermal (G), modified from 
156 ReportLinker [55], Power Companies (P), top ten after Walton, [56] and western International Oil and

157 Gas companies after Forbes, [57]. Solar PV - utility-scale solar photovoltaic.

158

\begin{tabular}{|c|c|c|c|c|c|c|c|c|c|c|c|c|c|}
\hline $\begin{array}{l}\text { Geothermal } \\
\text { Companies }\end{array}$ & Hydrogen & $\begin{array}{l}\text { Storage/ } \\
\text { Li-Battery }\end{array}$ & $\begin{array}{l}\text { Storage/ } \\
\text { H2- } \\
\text { Battery }\end{array}$ & $\begin{array}{l}\text { Fuel } \\
\text { Cell }\end{array}$ & $\begin{array}{l}\text { Gas to } \\
\text { Power }\end{array}$ & $\begin{array}{l}\text { Oil to } \\
\text { Power }\end{array}$ & Coal & Nuclear & $\begin{array}{c}\text { Gas } \\
\text { Exploration }\end{array}$ & $\begin{array}{c}\text { Oil } \\
\text { Exploration }\end{array}$ & $\begin{array}{c}\text { Electricity } \\
\text { Distribution/ } \\
\text { Transmission }\end{array}$ & cCus & Reference \\
\hline BHE (P) & & $\mathrm{x}$ & & & $x$ & & $\mathrm{x}$ & & & & $x$ & & [19] \\
\hline CALPINE (P) & & & & & & & & & & & & & [20] \\
\hline CLEAG (G) & & & & & & & & & & & & & [21] \\
\hline CLIMEON (G) & & & & & & & & & & & & & [22] \\
\hline EAVOR (G) & & & & & & & & & & & & & [23] \\
\hline Greenfire (G) & & & & & & & & & & & & & [24] \\
\hline Innergex (ERP) & & & & & & & & & & & & & [25] \\
\hline J-Power (P) & & & & & & & $x$ & $\mathrm{x}$ & & & $x$ & & {$[26]$} \\
\hline KenGen (P) & & & & & & & & & & & & & [27] \\
\hline ORMAT (G) & & $x$ & & & & & & & & & & & {$[28]$} \\
\hline Razor (E\&P) & & & & & & & & & $x$ & $x$ & & & [29] \\
\hline Terra-Gen (P) & & $x$ & & & & & & & & & & & [30] \\
\hline Power Companies & Hydrogen & $\begin{array}{l}\text { Storage/ } \\
\text { Li-Battery }\end{array}$ & $\begin{array}{l}\text { Storage/ } \\
\text { H2- } \\
\text { Battery }\end{array}$ & $\begin{array}{l}\text { Fuel } \\
\text { Cell }\end{array}$ & $\begin{array}{l}\text { Gas to } \\
\text { Power }\end{array}$ & $\begin{array}{l}\text { Oil to } \\
\text { Power }\end{array}$ & Coal & Nuclear & $\begin{array}{c}\text { Gas } \\
\text { Exploration }\end{array}$ & $\begin{array}{c}\text { Oil } \\
\text { Exploration }\end{array}$ & $\begin{array}{c}\text { Electricity } \\
\text { Distribution/ } \\
\text { Transmission }\end{array}$ & CCUS & Reference \\
\hline $\begin{array}{l}\text { Dominion } \\
\text { Resources (P) }\end{array}$ & & $\mathrm{x}$ & & & $\mathrm{x}$ & $\mathrm{x}$ & $\mathrm{x}$ & $\mathrm{x}$ & & & $\mathrm{x}$ & & [31] \\
\hline Duke Energy (P) & & $x$ & & & $\mathrm{x}$ & $x$ & $\mathrm{x}$ & $\mathrm{x}$ & & & $\mathrm{x}$ & & [32] \\
\hline EDF (P) & $x$ & $x$ & & & $x$ & $x$ & $\mathrm{x}$ & $x$ & & & $\mathrm{x}$ & & [33] \\
\hline ENEL (P) & & $x$ & $\mathrm{x}$ & & $x$ & $x$ & $\mathrm{x}$ & $\mathrm{x}$ & & & $x$ & & [34] \\
\hline ENGIE (ERP) & $x$ & $x$ & $x$ & $x$ & $x$ & & & $x$ & & & $\mathrm{x}$ & & [35] \\
\hline ELEXON (P) & & $x$ & & & $x$ & $x$ & & $x$ & & & $x$ & & [36] \\
\hline IBERDROLA (P) & & $x$ & & & $\mathrm{x}$ & & $\mathrm{x}$ & $x$ & & & $x$ & & [37] \\
\hline National Grid (P) & & $x$ & & & & & & & & & $x$ & & [38] \\
\hline NEXTERA (P) & & $x$ & & & $x$ & $x$ & $\mathrm{x}$ & $x$ & & & $\mathrm{x}$ & & [39] \\
\hline $\begin{array}{l}\text { Southern } \\
\text { Company (P) }\end{array}$ & & $\mathrm{x}$ & & & $x$ & & $\mathrm{x}$ & $x$ & & & $x$ & & [40] \\
\hline $\operatorname{EON}(\mathrm{P})$ & & $x$ & & & $\mathrm{x}$ & & & $x$ & & & $\mathrm{x}$ & & [41] \\
\hline ØRSTED (ERP) & & $x$ & & & & & & & & & $\mathrm{x}$ & & [42] \\
\hline O\&G Companies & Hydrogen & $\begin{array}{l}\text { Storage/ } \\
\text { Li-Battery }\end{array}$ & $\begin{array}{l}\text { Storage/ } \\
\text { H2- } \\
\text { Battery }\end{array}$ & $\begin{array}{l}\text { Fuel } \\
\text { Cell }\end{array}$ & $\begin{array}{l}\text { Gas to } \\
\text { Power }\end{array}$ & $\begin{array}{l}\text { Oil to } \\
\text { Power }\end{array}$ & Coal & Nuclear & $\begin{array}{c}\text { Gas } \\
\text { Exploration }\end{array}$ & $\begin{array}{c}\text { Oil } \\
\text { Exploration }\end{array}$ & $\begin{array}{c}\text { Electricity } \\
\text { Distribution/ } \\
\text { Transmission }\end{array}$ & CCUS & Reference \\
\hline OXY (O\&G) & & & & & $\mathrm{x}$ & & & & $\mathrm{x}$ & $\mathrm{x}$ & & $\mathrm{x}$ & [43] \\
\hline BP (O\&G) & $\mathrm{x}$ & $x$ & & $\mathrm{x}$ & & & & & $x$ & $x$ & & $\mathrm{x}$ & [44] \\
\hline Chevron (O\&G) & $x$ & $x$ & & & & & & & $x$ & $x$ & & $x$ & [45] \\
\hline CNR (O\&G) & $x$ & & & & & & & & $x$ & $\mathrm{x}$ & & $x$ & [46] \\
\hline $\begin{array}{l}\text { Conocophillips } \\
\text { (O\&G) }\end{array}$ & & & & & & & & & $x$ & $x$ & & $x$ & [47] \\
\hline Devon (O\&G) & & & & $x$ & & & & & $x$ & $\mathrm{x}$ & & & [48] \\
\hline ENI (O\&G) & $x$ & $x$ & & & $\mathrm{x}$ & & & $x$ & $x$ & $x$ & & $\mathrm{x}$ & [49] \\
\hline Equinor (O\&G) & $x$ & $x$ & & $x$ & $x$ & & & & $x$ & $x$ & $x$ & $\mathrm{x}$ & [50] \\
\hline SHELL (O\&G) & $x$ & $\mathrm{x}$ & & $x$ & $\bar{x}$ & & & & $x$ & $x$ & $x$ & $x$ & [51] \\
\hline Suncor (O\&G) & $x$ & & & & $\mathrm{x}$ & & & & $x$ & $x$ & & $x$ & [52] \\
\hline TOTAL (O\&G) & $x$ & $x$ & & $\mathrm{x}$ & $x$ & & $\mathrm{x}$ & & $x$ & $\mathrm{x}$ & $\mathrm{x}$ & $x$ & [53] \\
\hline $\begin{array}{l}\text { ExxonMobil } \\
\text { (O\&G) }\end{array}$ & & $x$ & & $x$ & & & $\mathrm{x}$ & & $x$ & $x$ & & $x$ & [54] \\
\hline
\end{tabular}




\begin{tabular}{|c|c|c|c|c|c|c|c|c|c|c|c|c|}
\hline Trend Analysis & Hydrogen & $\begin{array}{l}\text { Storage/ } \\
\text { Li-Battery }\end{array}$ & $\begin{array}{l}\text { Storage/ } \\
\text { H2- } \\
\text { Battery }\end{array}$ & $\begin{array}{l}\text { Fuel } \\
\text { Cell }\end{array}$ & $\begin{array}{l}\text { Gas to } \\
\text { Power }\end{array}$ & $\begin{array}{l}\text { Oil to } \\
\text { Power }\end{array}$ & Coal & Nuclear & $\begin{array}{l}\text { Gas } \\
\text { Exploration }\end{array}$ & $\begin{array}{l}\text { Oil } \\
\text { Exploration }\end{array}$ & $\begin{array}{l}\text { Electricity } \\
\text { Distribution/ } \\
\text { Transmission }\end{array}$ & CCUS \\
\hline TOTAL & 10 & 22 & 2 & 7 & 17 & 6 & 11 & 12 & 13 & 13 & 17 & 11 \\
\hline Geothermal (12) & 0 & 3 & 0 & 0 & 1 & 0 & 2 & 1 & 1 & 1 & 2 & 0 \\
\hline Power (12) & 2 & 12 & 2 & 1 & 10 & 6 & 7 & 10 & 0 & 0 & 12 & 0 \\
\hline O\&G (12) & 8 & 7 & 0 & 6 & 6 & 0 & 2 & 1 & 12 & 12 & 3 & 11 \\
\hline
\end{tabular}

Table 1b: Industry diversification trends. Extracted from Year End shareholder and sustainability reports published in 2018, (see references). Twelve companies from Geothermal (G), modified from ReportLinker [55], Power Companies (P), top ten after Walton, [56] and western International Oil and Gas companies, Forbes, [57]..

\begin{tabular}{|c|c|c|c|c|c|}
\hline $\begin{array}{l}\text { Geothermal } \\
\text { Companies }\end{array}$ & $\begin{array}{c}\text { Total } \\
\text { Diversification }\end{array}$ & Power Companies & $\begin{array}{c}\text { Total } \\
\text { Diversification } \\
\end{array}$ & $\begin{array}{c}\text { O\&G } \\
\text { Companies }\end{array}$ & $\begin{array}{c}\text { Total } \\
\text { Diversification }\end{array}$ \\
\hline BHE (P) & 9 & EDF (P) & 15 & SHELL (O\&G) & 16 \\
\hline J-Power (P) & 6 & ENEL (P) & 14 & Equinor (O\&G) & 15 \\
\hline KenGen (P) & 5 & ENGIE (ERP) & 14 & TOTAL (O\&G) & 15 \\
\hline Innergex (ERP) & 4 & $\begin{array}{l}\text { Dominion Resources } \\
(\mathrm{P})\end{array}$ & 11 & BP (O\&G) & 12 \\
\hline ORMAT (G) & 4 & IBERDROLA (P) & 11 & ENI (O\&G) & 12 \\
\hline Terra-Gen (P) & 4 & EON (P) & 11 & Suncor (O\&G) & 9 \\
\hline Razor (O\&G) & 3 & ELEXON (P) & 10 & ExxonMobil (O\&G) & 8 \\
\hline CLIMEON (G) & 2 & Duke Energy (P) & 9 & Chevron (O\&G) & 7 \\
\hline CALPINE (P) & 1 & Southern Company (P) & 9 & OXY (O\&G) & 6 \\
\hline CLEAG (G) & 1 & $\varnothing$ RSTED (ERP) & 9 & CNR (O\&G) & 6 \\
\hline $\operatorname{EAVOR}(G)$ & 1 & NEXTERA (P) & 8 & ConocoPhillips (O\&G) & 4 \\
\hline GreenFire (G) & 1 & National Grid (P) & 5 & Devon (O\&G) & 3 \\
\hline
\end{tabular}

Table 1c: Industry diversification trends, ranked by technology. For energy technology description see tables 1a and 1b. Company type: P- Power Company, ERP - Emerging Renewable Power Company, G - Geothermal Company, O\&G - Oil and Gas Company.

\subsection{ADOPTION OF GEOTHERAM/THERMAL TECHNOLOGIES IN THE ENERGY DIVERSIFICATION}

Analysis of the geothermal/thermal technology diversification of the 36 studied companies reveals additional insights into the limited uptake of this low-carbon baseload technology (Table 2). As with the analyses in Tables $1 a$ and $1 b$, if the values are taken at face value, without knowing the amount spent, the power produced the following trends are observed: (1) the most popular thermal 
172 technology is the application of waste heat, which is not strictly a geothermal technology, although it

173 shares much of the above ground technology. (2) Conventional geothermal using flash steam

174 technologies are the second most popular geothermal technology in use. (3) The most diversified 175 companies in geothermal/thermal technologies are: SHELL, EDF and ENEL, each with four 176 geothermal/thermal technologies in their portfolio. (4) The most diversified geothermal company is 177 ORMAT, with three geothermal technologies. The paradox here is that power companies and an O\&G company are more diversified in geothermal/thermal than a company that exploits heat as its core business. (5) The O\&G and power companies that are publicly engaged in research and development in the geothermal domain appear to be largely involved in conduction closed-loop and supercritical technologies. These companies are SHELL, Equinor, ENEL and J-Power. (6) Only EDF and Equinor are playing the EGS technology, the former with the world's first commercial power plant located in France. (7) District energy is largely developed by European renewable and power sectors (EDF, ENGIE, EON, ORSTED, SHELL). (8) In the power industry it is common for companies to be in both waste-heat and geothermal. (9) Power and O\&G companies are investing in waste-heat, yet it is not common for them to have district energy or geothermal heat-pumps. The companies that diverge are ENGIE, ØRSTED, EDF, all of which are power companies. (10) only one company appears to be developing geothermal power project at existing oil and gas facilities.

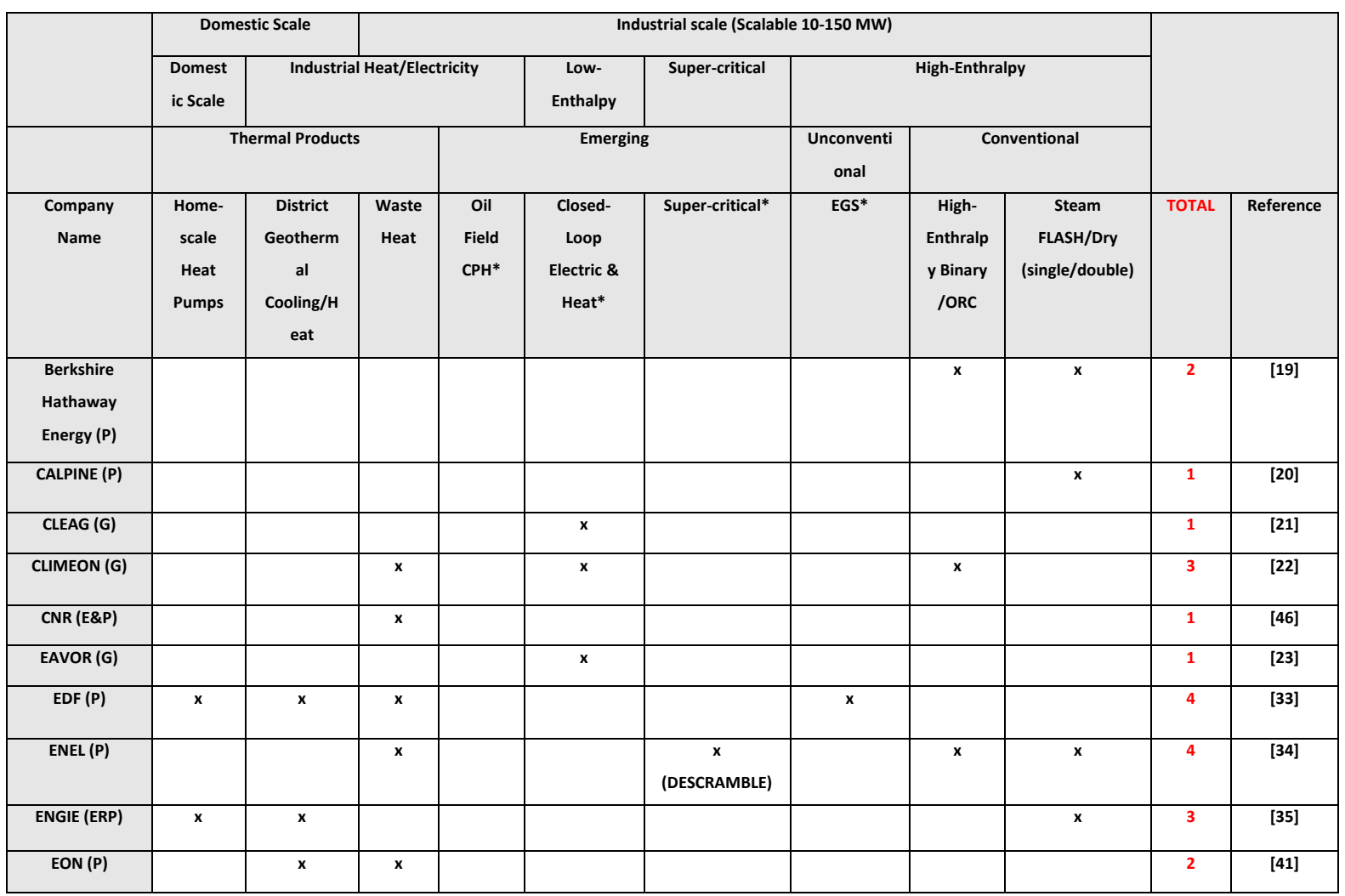




\begin{tabular}{|c|c|c|c|c|c|c|c|c|c|c|c|}
\hline Equinor (O\&G) & & & $x$ & & & $x$ (IDDP) & $\begin{array}{c}\mathrm{X} \\
\text { (DEEPEGS) }\end{array}$ & & & 3 & [50] \\
\hline $\begin{array}{c}\text { ExxonMobil } \\
\text { (O\&G) }\end{array}$ & & & $x$ & & & & & & & 1 & [54] \\
\hline GreenFire (G) & & & & & $x$ & $x$ & & & & 2 & [24] \\
\hline IBERDROLA (P) & & & $x$ & & & & & & & 1 & [37] \\
\hline Innergex (P) & & & & & & & & $x$ & $x$ & 2 & [25] \\
\hline J-Power (P) & & & & & & $x$ (Greenfire) & & & $\mathrm{x}$ & 2 & [26] \\
\hline KenGen (P) & & & $x$ & & & & & & $\mathrm{x}$ & 2 & [27] \\
\hline ORMAT (G) & & & $x$ & & & & & $x$ & $x$ & 3 & [28] \\
\hline ØRSTED (ERP) & $x$ & $\mathrm{x}$ & $x$ & & & & & & & 3 & [42] \\
\hline OXY (O\&G) & & & $x$ & & & & & & & 1 & [43] \\
\hline Razor (O\&G) & & & & $\mathrm{x}$ & & & & & & 1 & [29] \\
\hline SHELL (O\&G) & & $x$ & $x$ & & $x$ (EAVOR) & $x$ (Greenfire) & & & & 4 & [51] \\
\hline Suncor (O\&G) & & & $x$ & & & & & & & 1 & [52] \\
\hline Terra Gen (P) & & & & & & & & & $\mathrm{x}$ & 1 & [30] \\
\hline TOTALS & 3 & 5 & 14 & 1 & 5 & 5 & 2 & 5 & 9 & & \\
\hline
\end{tabular}

Table 2: Detailed analysis of Geothermal and waste heat technologies (extracted and compiled from End of Year Reports and sustainability reports from 2018, see references). * Emerging geothermal technology. CPH - Coproduced heat. ORC - Organic Rankine Cycle technology for closed-loop; EGS - Enhanced Geothermal System; GSHP - Ground Sourced Heat Pump. (DESCRAMBLE) indicates a research and development project or collaboration, DESCRAMBLE Project [58], IDDP and DEEP ESG [59], EAVOR [23] and GreenFire [24].

Twenty semi-structured interviews formed the basis of the primary data collection for this exploratory research (Table 3). The completed interviews ranged from 130 to 45 minutes, with an average of 81.5 minutes +/- 25.6 minutes. From the interview pool, the average work experience in geothermal industries was $8.7,+/-9.0$ years. The spread of work experience was from 1 year to 35 years. Eleven of the twenty interviews were USA based geothermal experts, eight from the European region (EU and EEA) and one from Asia. While six interviewees did not have experience in the USA geothermal markets, their experience and opinions were very useful for the understanding of issues within the geothermal markets. Overall, the dominant experience was from California with 13 of 20 candidates having experience in California. The interviews accessed a spread of backgrounds with the exception of regulatory and the Power sectors.

\begin{tabular}{|c|c|c|c|c|c|c|c|c|c|c|}
\hline Code & Gender & Location & LOCATION & Experience & $\begin{array}{c}\text { Technical } \\
\text { Background }\end{array}$ & Role & $\begin{array}{c}\text { Experience } \\
\text { Base }\end{array}$ & $\begin{array}{c}\text { US } \\
\text { Experience } \\
\text { Base }\end{array}$ & $\begin{array}{c}\text { Present Company } \\
\text { Type }\end{array}$ & $\begin{array}{c}\text { Interview } \\
\text { Length }\end{array}$ \\
\hline
\end{tabular}




\begin{tabular}{|c|c|c|c|c|c|c|c|c|c|c|}
\hline GEOTH002 & Male & USA & USA & 35 & Engineer & Consultant & International & California & $\begin{array}{ll}\text { Consulting } & - \\
\text { Geothermal } \\
\text { Development }\end{array}$ & 130 \\
\hline GEOTH003 & Male & $\begin{array}{l}\text { EEA } \\
\text { Area }\end{array}$ & Switzerland & 6 & Business & $\begin{array}{l}\text { Business } \\
\text { Development }\end{array}$ & International & $\mathrm{N} / \mathrm{A}$ & $\begin{array}{l}\text { Geothermal } \\
\text { Startup }\end{array}$ & 84 \\
\hline GEOTH004 & Male & USA & USA & 25 & Business/Economics & Leader & International & California & $\begin{array}{l}\text { Geothermal } \\
\text { Startup }\end{array}$ & 102 \\
\hline GEOTH006 & Male & USA & USA & 2 & Geoscientist & Leader & USA & California & $\begin{array}{l}\text { Geothermal } \\
\text { Startup }\end{array}$ & 46 \\
\hline GEOTH012 & Male & USA & USA & 4 & Geoscientist & Leader & International & All & $\begin{array}{l}\text { International E\&P } \\
\text { Company }\end{array}$ & 91 \\
\hline GEOTH014 & Male & USA & USA & 20 & Geoscientist & Leader & USA & California & $\begin{array}{l}\text { Institution } \\
\text { Geothermal } \\
\text { Association }\end{array}$ & 64 \\
\hline GEOTH015 & Male & $\begin{array}{l}\text { EEA } \\
\text { Area }\end{array}$ & Iceland & 10 & Legal & Leader & International & N/A & $\begin{array}{l}\text { Institution } \\
\text { Geothermal } \\
\text { Marketing }\end{array}$ & 97 \\
\hline GEOTH017 & Male & USA & USA & 10 & Geoscientist & Consultant & International & $\begin{array}{l}\text { Nevada, } \\
\text { California }\end{array}$ & $\begin{array}{l}\text { Consulting } \\
\text { Geothermal } \\
\text { Consulting }\end{array}$ & 96 \\
\hline GEOTH018 & Male & Europe & France & 3 & Engineer & Investment & International & California & $\begin{array}{l}\text { International E\&P } \\
\text { Company }\end{array}$ & 59 \\
\hline GEOTH020 & Female & USA & USA & 15 & Geoscientist & Leader & International & ALL & $\begin{array}{l}\text { Institution } \\
\text { Governmental }\end{array}$ & 75 \\
\hline GEOTH022 & Female & Europe & Netherlands & 2 & Econocmics & $\begin{array}{l}\text { Project } \\
\text { Manager }\end{array}$ & International & Texas & $\begin{array}{l}\text { Institution } \\
\text { Governmental }\end{array}$ & 58 \\
\hline GEOTH023 & Female & Europe & Sweden & 2 & Geoscientist & Investment & International & All & $\begin{array}{l}\text { Geothermal } \\
\text { Startup }\end{array}$ & 67 \\
\hline GEOTH024 & Male & Europe & Denmark & 1 & Engineer & Technical & International & $\mathrm{N} / \mathrm{A}$ & $\begin{array}{l}\text { Geothermal } \\
\text { Startup }\end{array}$ & 97 \\
\hline GEOTH025 & Male & USA & USA & 2 & Engineer & Leader & USA & ALL & $\begin{array}{l}\text { Geothermal } \\
\text { Startup }\end{array}$ & 57 \\
\hline GEOTH027 & Male & Asia & Japan & 2 & Geoscientist & Technical & International & N/A & $\begin{array}{l}\text { Geothermal } \\
\text { Startup }\end{array}$ & 90 \\
\hline GEOTH028 & Male & Europe & Ireland & 1 & Geoscientist & Consultant & International & N/A & $\begin{array}{l}\text { Consulting } \\
\text { Energy Transition }\end{array}$ & 81 \\
\hline GEOTH029 & Female & Europe & UK & 8 & Geoscientist & Sales & International & N/A & $\begin{array}{l}\text { Consulting } \\
\text { Service Industry/ } \\
\text { Software }\end{array}$ & 108 \\
\hline GEOTH030 & Male & USA & USA & 10 & Marketing & Leader & International & All & $\begin{array}{l}\text { Geothermal } \\
\text { Marketing }\end{array}$ & 45 \\
\hline GEOTH031 & Male & USA & USA & 6 & Business & $\begin{array}{l}\text { Business } \\
\text { Development }\end{array}$ & International & All & $\begin{array}{l}\text { Consulting } \\
\text { Geothermal } \\
\text { Development }\end{array}$ & 51 \\
\hline GEOTH032 & Female & USA & USA & 10 & Legal & Leader & International & All & $\begin{array}{l}\text { Institution } \\
\text { Academic }\end{array}$ & 130 \\
\hline
\end{tabular}

210 Table 3: Profiles of those interviewed, with identity protected to maintain confidentiality. GEOTH001

211 for example is a code given to the first invited expert and their response was anonymized using this 212 code. 
215 The benefit of semi-structured interviews is that they can be used to gain an insight into complex problems. The interviews were broad and in-depth, with some interviews lasting as long as 130 minutes (Table 3). The transcribed interviews were loaded into NVIVO v12 for quantitative analysis [60]. The interviews were semi-manually coded within the software, key words combined with their synonyms were screened across all twenty transcribed interviews. NVIVO uses basic natural language processing to aid the rapid coding of the transcriptions. Finally, the coded terms were organized into identified themes to address the research aims (Table 4). The interviews were designed to answer the following questions: What are the barriers to the O\&G adoption of geothermal? And, what is the external operating environment for the Geothermal industry in the USA? For the latter the following themes were identified: Political, Economic, Social, Technological, Legal and Environmental. These themes combine to form what is known as a PESTLE analysis [61]. The PESTLE analysis is a strategic framework used to understand the present-day external environment of the geothermal industry in the USA.

\begin{tabular}{|c|c|c|}
\hline Theme & Files (Interviews) & Codes (Total Including Sub-Themes) \\
\hline Barriers to Geothermal & 20 & 238 \\
\hline Politics & 17 & 142 \\
\hline Economics & 18 & 48 \\
\hline Social & 14 & 169 \\
\hline Technological & 19 & 18 \\
\hline Legal & 7 & 23 \\
\hline Environmental & 9 &
\end{tabular}

Table 4: Table showing the main themes and the number of interviews that discussed these themes and or their sub-themes. The codes were attributed to the themes after manual coding.

\section{4: BARRIERS TO OIL AND GAS ADOPTION OF GEOTHERMAL}

Tables 1 and 2 revealed that of the major O\&G companies only SHELL and Equinor are investing resources in geothermal technology development. Yet, it is worth commenting that their investments are not in the conventional domain. Those power companies that are in geothermal appear to have entered into it through merger and acquisition activities. Although a few of the power companies are developing geothermal with ENEL, EDF, ENGIE, KenGen, and J-Power all investing in new developments and geothermal technology development. that companies the scale of O\&G could assist in developing the needed technological advances which 
240 could help make geothermal a sustainable baseload for the future (GEOTH020; GEOTH032). In fact 11 241 of 20 experts thought that engagement with $O \& G$ companies was beneficial to overcoming many of 242 the barriers due to the scale of resources an O\&G company can bring (Public Relations (PR), experience, legal, drilling, subsurface, financial, systems/control). It was highlighted that O\&G's involvement in the geothermal industry would be a "game-changer" (GEOTH014). Furthermore, a key argument cited was that the conventional geothermal industry is "20-30 years out of date" (GEOTH015; GEOTH020; GEOTH028; GEOTH032).

Yet, it was acknowledged that there were significant barriers that highlight why O\&G companies currently find it hard to adopt conventional and unconventional geothermal technologies. The top barriers are summarized in order of importance in Table 5. It is clear that there are many technical/operational, commercial, legal and stakeholder barriers. Furthermore, there are a clear failures to manage public relations and educational aspects. The failure to bring along governments, local administration and the public has resulted in many people simply rejecting the geothermal development concept before they know what it is. While many of these issues are directly linked to conventional and unconventional geothermal, educational ignorance and pattern of life (owner vs renter and short-term economic/policy vision), particularly for GSHP and district energy developments. It is however, clear that the stakeholder management and educational aspects extends to all existing and future geothermal technologies.

A strategic fit was proposed between the geothermal industry and the $O \& G$ industry rather than the power industry because: (a) the O\&G industry is highly experienced in managing risk and capitally intensive projects over longer timelines. (b) They also have many of the required skills that can be utilized for the sub-surface, engineering, drilling and project management requirements associated with geothermal development. (c) If the O\&G industry do not diversify they may not survive as an industry, they need to maintain a social license to operate, which geothermal can give them. (d) Several companies are already diversifying and entering the utility markets with other renewables, (e) Ultimately, because of the size of their PR, Lobbying and financial resources and the scale of O\&G companies can lead to an "overnight $20 \%$ cost reduction in drilling and casing, due to an economy of scale" (GEOTH015).

With respect to O\&G companies the major reason for lack of interest was simply down to the return on investment (GEOTH018). It was bluntly put by GEOTH0O2 "O\&G companies simply make too much money from oil and gas to be bothered with geothermal". Other interviewees, proposed that it was 
272 (GEOTH002), and (b) geothermal development timelines were "too long" and the resources "too 273 small" and when compared to wind and solar PV when looking to "quickly develop 25GWe" 274 (GEOTH018). The remoteness or miss-alignment of geothermal resources and population centers 275 (GEOTH002) which intensifies the issues of geothermal heat and derived power in the discussion of commodity vs utility (GEOTH002). The arguments always boil down to money and this underpinning the reason for O\&G not being involved in geothermal. Essentially a lack of incentives and the lack or return on investment, for example: "You have the same risk, but you have the financial returns of a utility company" (GEOTH015). Finally, one aspect that is insightful from the perspective of an international O\&G company was scale. "[O\&G tend] to have global operations, and the problem with a new conventional geothermal business stream is that it is only available to nine percent of the world" (GEOTH012).

Innovation within the geothermal industry including, low-temperature closed-loop and closed-loop conduction technologies, does, however, give some hope for decoupling geographic restrictions and geothermal heat and power (GEOTH020; GEOTH032). Increasing the footprint of the geothermal industry, with scalable, baseload concepts, might provide an avenue for the oil and gas industry to enter the geothermal domain, while leveraging their existing core competencies, IP, technology, assets, and workforce knowledge skills and experience (GEOTH012).

\subsubsection{Recommended pathway or solutions to stimulate geothermal development}

292

293

Thirteen of twenty experts offered solutions how governments can stimulate activities these are summarized also in Table 6, although not ranked in order of importance. The inclusion of the O\&G industry is however not a prerequisite however to the proliferation of geothermal, there are other mechanisms or levers that governments could use to develop an industry that is ripe and innovating at high rates. A number of experts proposed that a carbon price or carbon trading scheme might encourage O\&G companies [GEOTH002; GEOTH003; GEOTH012; GEOTH014; GEOTH015; GEOTH025; GEOTH029]. Major criticism in the USA during interviews, was directed at the failure of governmental policy, its inconsistency and the bias or failure of incentivization schemes that did not account for baseload development. It is clear that a long-term, baseload incentive scheme for at least 15 years would incentivize geothermal development. It was also voiced during some interviews that if government energy policy would replicate the incentives the $O \& G$ industry have enjoyed this would likely lead to significant innovation and exploration in the area [GEOTH004; GEOTH032]. A number of interesting proposals with respect to how governments can regulate were proposed these range from 


\begin{tabular}{|l|}
\hline Top technical/operational barriers to geothermal: \\
\hline Subsurface risk and uncertainty \\
\hline Induced seismicity \\
\hline Water demand \\
\hline Environmental discharges \& corrosion \\
\hline Heatloss \\
\hline Heatflow \\
\hline Fracking \\
\hline Safety \\
\hline Top commercial barriers to geothermal: \\
\hline Return on investment \\
\hline Cost drilling and casing \\
\hline Policy bias or lack of importance attributed to baseload power \\
\hline Access to PPA and price protection for geothermal (baseload) \\
\hline Highly capital intensive \& time to develop geothermal \\
\hline Scale of resource size (barrier to O\&G) \\
\hline Commercial success rate \\
\hline Remote locations \& not a commodity i.e. non-transportable \\
\hline Cheap US electricity - market competition \\
\hline Limited geographic penetration globally (lack of running room) \\
\hline Top non-technical/commercial barriers to geothermal: \\
\hline Failure in Public Relations and marketing \\
\hline Education i.e. lack of knowledge leading to inherent misconceptions \\
\hline Stakeholder alignment \\
\hline Legal framework - redevelopment of oil and gas fields \\
\hline Success of E\&P fracking managing land and access and drilling permits \\
\hline
\end{tabular}

Recommended pathway or solutions to stimulate geothermal development:

Get oil and gas interested to reduce costs and manage PR and government

Carbon Trading or Carbon Tax Schemes needed

Long-term (15-20 years) Government led energy policy incorporating low-carbon baseload energy with

incentives for development of heat and power

Valorization of heat with new business models

Governments need to offer baseload Renewable Energy Certificates (RECS) - which incentivize companies to develop baseload low-carbon power.

Government tax breaks for exploration and R\&D (e.g. Norway which allowed Norway allowed companies since 2005 to deduct $78 \%$ of their exploration costs from taxable income).

Fast-track geothermal permitting and exploration licenses. 
Develop an energy efficiency scheme for homes/buildings which impact value of homes Government/Industry led drilling-insurance incentive scheme for drilling (failed wells $80 \%$ return on cost - successful wells pay additional tax on development for 10 years)

Have Government led thermal and hydrothermal exploration (As recently announced in

Japan/Indonesia)

311 Table 6: Recommendations to stimulate geothermal development

\section{5: THE EXTERNAL ENVIRONMENT FOR THE GEOTHERMAL INDUSTRY}

The interviews responses were organized to give a PESTLE analysis of the present-day external environment of the geothermal industry in the USA today.

\subsubsection{Political}

In relation to conventional and unconventional geothermal technologies many interviewees acknowledge the work of the US Department Of Energy (DOE) and the National Renewable Energy Laboratory (e.g. NREL), or the United States Geological Survey (USGS), (GEOTH012; GEOTH025). Much of this work has led to the characterization of the geological environment and heat-flow in the USA or in setting up demonstration sites for geothermal research (GEOTH012, GEOTH020; GEOTH025). Meanwhile many were critical of the "cyclicity" of policy (e.g. Public Utility Regulatory Policies Act (PURPA) which did not last long enough to enable the geothermal industry to get going (GEOTH004). The policy cyclicity has meant that no policy period has given the 15 years' of support that the industry needs to enable it to make significant progress (GEOTH003). In addition, there was extensive criticism of the effectiveness of the Geothermal Resource Council (GRC) which is based in California (GEOTH004). It was argued that the GCR has failed to protect and market geothermal industries as a renewable and baseload source and to challenge the government with respect to its policies on global warming (GEOTH025).

Several interviewees argued that California forms the most interesting State in the USA to examine the clash between State vision and the lack of a Federal vision over climate change and energy policy. In contrast to the current Trump Administration (2016-2020), California is extremely progressive in its outlook for GHG reductions, with the revised SB-100 Bill (GEOTH025). The geographic overlap between geothermal technologies and wind, solar PV and storage and aggressive state decarbonization goals make California a potential front-line between dispatchable and nondispatchable technologies. Because of policy-bias towards wind and solar PV, driven in part, among 
exponential. The policy bias led GEOTHOO4 and others to argue that there is a need for honest assessment of the cost of energy, because current LCOE do not consider the costs of ramping up and down the essential backup baseload energy technologies: geothermal, hydro, coal, gas and nuclear, (GEOTH002; GEOTH004). Neither do current LCOE reveal the cost of storage facilities, grid integration costs and emissions (GEOTH002).

Other policies that have been extensively discussed in relation to California or sometimes Texas are the Renewable Portfolio Standards (RPS) which are placing geothermal at a disadvantage because there is no expression of which energy technology should be used (GEOTH002). This therefore leads businesses and investors to look at what is the fastest and cheapest to deploy, and with the other tax incentives this is wind and or solar PV (GEOTH002). It was proposed that if these policies are renewed they need to have a component that protect energy from baseload sources (GEOTH002).

In summary, the U.S. federal, political environment of climate denial (GEOTH025), inaccurate assessment of energy pricing (GEOTH004), policy bias with respect to tax credits and financial incentives provides a challenging business environment for the conventional and unconventional geothermal industry within the USA (GEOTH002; GEOTH003; GEOTH004; GEOTH006; GEOTH012; GEOTH018). The biggest issue was that there was no coherent energy policy that valued a renewable and sustainable baseload energy (GEOGH004; GEOTH032). This is driven by political short-termism and a refusal to address energy security and climate change in the USA, largely due to a long-term belief that the USA should have cheap electricity and a central reliance on the oil and gas industry and policies that favor it or do not limit its production or use. Because of these combined factors in the USA the direct application of geothermal technologies, which is a mature technology, is severely under-utilized. Finally, the expectation that policy bias may change is low, largely because in the USA regulation and government interference is not tolerated, unlike many other parts of the world (GEOTH027). In some respects, the future of the geothermal industry in the USA, seems to be in the hands of climate-aware private investors, unless there is a significant change with respect to governmental policy (GEOTH002; GEOTH006; GEOTH012; GEOTH017; GEOTH025; GEOTH032).

\subsubsection{Economic}

A positive economic case for the geothermal industry is that in the USA there is a hugely skilled workforce in large part due to crossover with the oil and gas industry (GEOTH012). Plus, there are many university specialist departments and research groups and institutions in the USA (GEOTH025; GEOTH032). However, a key energy characteristic of the USA is its history of low-cost electricity and abundant oil and gas. Historically the fluctuation of oil and gas price, worries over energy security, 
370 and government policy has influenced the involvement of $O \& G$ companies in the geothermal industry, over time (GEOTH004). When the price of oil was high or there were geopolitical issues and energy security issues, geothermal was on the agenda. More recently, the overwhelming success of the oil and gas industry with fracking has served to give the USA an oil and gas surplus which no one would have thought possible 15 years ago (GEOTH032).

Short-termism and low-cost are the apparent barriers to advancement of geothermal energy, with investors prioritizing quick returns with investments in wind and solar PV (GEOTH002). Secondly, the fact that investors earn more money from the development of fossil-fuel infrastructure (GEOTH002). Thirdly, the distances from resource to population centers, combined with value mechanism for heat means that many geothermal projects remain uneconomic. A discussed example that was brought up is the San Diego Gas and Electric company. This company has zero megawatts of geothermal, but it has big investments in both in solar PV and wind and gas turbines, even though they operate in a region where some of the best geothermal resources have been characterized (GEOTH002). While rate payers are not affected, the problem is both economic, political and educational. Because, it is investors who benefit from the building of combined cycle gas turbines, which are constructed cheaply to support and supplement the development of, cheap, non-dispatchable wind and solar PV. Gas turbines were selected rather than using a local sustainable geothermal resource, which is considerably lower in emissions. The lack of planning, combined with inconsistent carbon mitigation policies allow power companies to follow the cheapest economic solution, regardless of the environmental impact. The resulting fallout is that while rate payers are not economically affected, their power supply does not align with the Paris Treaty Agreement, even though a low-carbon baseload is available on their doorstep (GEOTH002). in California did demonstrate an ability to reduce GHG emissions, however it has resulted in daytime prices crashing, this is problematic when an unregulated market allows the energy company to simply buy the cheapest power. With abundant solar PV, geothermal energy is not able to compete especially when prices are negative (GEOTH025). GEOTH025 explained that there may be some geothermal optimism in the next ten years for geothermal power industry. The Californian integrated resource plans show that somewhere between 2022 and 2026 the state will have so much solar PV that daylight hours will be supplied by solar PV derived power. The implication is that cheap gas will fill the gap. But the SB-100 bill requires up to $60 \%$ decarbonization of the energy infrastructure, meaning geothermal could gain some traction looking forward. However, there is a new emerging threat to 
403

404

405

406

407

408

409

410

411

412

413

414

415

416

417

418

419

420

421

422

423

424

425

426

427

428

429

430

431

432

433

434

economic window of opportunity to develop geothermal resources, in order to supply a flexible, lowcarbon, baseload power at night-time (GEOTH004; GEOTH025).

Geothermal ultimately cannot compete head-to-head with onshore wind and solar PV, however, the hidden costs of non-dispatchable technology are not reported in LCOE calculations. This lead several interviewees to propose there is no honesty in the reporting of energy costs which in turn leads to policy bias (GEOTH002; GEOTH003; GEOTH004). A key question was proposed by GEOTH002, which is that the discussion on economics should not be can geothermal compete, but rather how can it reduce GHG emissions in a cost effective way over the long-term? Whether we talk about Conventional heat and power or indeed direct use via GHSP or district energy, the discussion should also focus on the value of grid stability geothermal brings as a result of its baseload nature and combined with the fact it provides cost-efficient carbon emissions abatement.

At the scale of GSHP, GEOTH002 provided a good argument for the role these simple technologies can play. Yet the advantages are not spoken of and it is ultimately the homeowner who shoulders all the risk of the investment. The GSHP, is the perfect example of distributed benefits without the beneficiaries paying. All the investment is made by the homeowner, yet his/her investment impacts the ratepayers because of the grid stability the GSHP brings. GSHP behave as a baseload and help to reduce the peaks and troughs in the energy supply. Therefore, everyone benefits but the Power company has not had to contribute a penny (GEOTH002). Cost is largely cited as a prohibitive issue for GSHP because individual projects can become costly. One solution proposed was that innovation could impact the costs and entrepreneurial businesses could develop business models, building partnerships with banks, suppliers, drillers that open up economies of scale, thus dropping costs (GEOTH002).

Ironically geothermal companies repeat the process, but at scale, because a barrel of steam, it is not a commodity like oil, which can be transported (GEOTH002; GEOTH017). A geothermal developer has to invest in converting the steam to electricity and selling the electricity. This requires a Public Purchase Agreement (PPA) or selling electricity on the marketplace, where prices can vary according to demand (GEOTH012). When trying to win investment the economics of a geothermal plant fail without the guarantee of a PPA (GEOTH017). This poses a second problem, as an independent electricity or heat producer, there are three fundamental economic issues: (1) electricity is cheap and plentiful in the USA (GEOTH002); (2) heat is a commodity that does not have a clear business value at least in the USA; (3) when selling electricity, no one makes significant money from the sale of electricity on a 30-year contract, especially not the geothermal distributor who does not benefit from 
435 the peaks or variability of non-dispatchable technologies. The only group that would ultimately benefit are the rate-payers. The general problem with this is that currently the environment and rate payer interests and those of the investors, are not aligned (GEOTH002). No investors earn money if power is bought from a geothermal developer. Investors earn money if a utility company owns and builds its own power plants (GEOTH002; GEOTH004). One solution perhaps is that geothermal companies could develop themselves as integrated energy companies.

441 One of the issues relating to the economics of geothermal developments is that geothermal is often identified as a niche industry with boutique development that are non-reproducible. In relation to how to drive costs down, several interviewees had opinions (Table 3b). Critically, smarter integration of oil and gas technology and exploration methods were cited (GEOTH015; GEOTH020; GEOTH032). Oil and gas practices using a portfolio approach improve chances of locating and drilling the best resources (GEOTH006; GEOTH015; GEOTH032). Finally, economies of scale were argued for because a company the size of an oil and gas company could bring down costs because of the scale of its business.

\subsubsection{Societal}

The interviews reveal that there is an unfortunate problem that most stakeholders, investors, decision makers and the general public do not know or understand what geothermal is and what it can mean to them. Geothermal needs to educate and challenge people's perceptions, for example geothermal does not require that you live next to a volcano, neither does geothermal cause environmental damage.

The issues of global warming and climate change are complex, and many stakeholders do not understand them, or deny they exist (GEOTH004; GEOTH006; GEOTH015; GEOT017; GEOTH22;

457 GEOTH025; GEOTH027; GEOTH030). It is not surprising therefore that when it comes to policy 458 geothermal technologies do not get considered, because no one fully understands the grid stability 459 and the environmental benefits, meaning lower GHG emissions and flexible baseload heat and power, 460 that geothermal can bring (GEOTH002; GEOTH025). Geothermal companies have historically failed to 461 educate the stakeholders, with the GRC coming under fire in several interviews (GEOTH004, GEOTH025). Currently in the USA most geothermal projects are limited to power production. But in reality, a creative use of the heat which could be daisy-chained or cascaded down into the community for different uses, could provide significant benefits to an ecosystem of businesses and communities (GEOTH012). 
466 Geothermal whether conventional, unconventional, low-temperatures, or advanced can also create jobs and importantly it can save people money in the long-term, because they do not need to purchase electricity or gas (GEOTH002; GEOTH004; GEOTH012; GEOTH15; GEOTH020). "There are huge societal benefits of geothermal - district heating and heat pumps, but no one is talking about them openly. They want us to keep buying fossil fuel derived power" (GEOTH002). It was also noted that installing a GSHP while saving $50 \%$ of required energy, it may even add value to the price of a property (GEOTH012). It was highlighted furthermore that geothermal ultimately contributes to energy stability, and could reduce energy poverty, particularly for lower income families, if the costs of installation can benefit "kitchen table economics" (GEOTH028)

In summary, the geothermal industry needs to market the value of power and direct use heating and cooling. This can be achieved by working with architects, city/town planners and business to develop geothermal ecosystems so businesses and homes can maximize benefit from the technology and developments. The geothermal industry also needs to better highlight the local/regional economic benefits, in particular jobs creation. The geothermal industry needs to engage with universities to protect the supply of geoscientists entering the work force, and help retrain those redundant from the O\&G industry. Additionally, the geothermal industry needs to engage with the oil and gas industry, if not for participation or support, but to learn from these organizations and capitalize and on the potential cross-overs and skills overlap (GEOTH012; GEOTH032).

\subsubsection{Technological}

Conventional geothermal is only seen as viable in about $9 \%$ of the world (GEOTH012). While unconventional (EGS) is seen as a technological breakthrough by some (GEOTH014; GEOTH025) a significant number of others do not see it as having potential (GEOTH002; GEOTH004; GEOTH012; GEOTH15; GEOTH20; GEOTH031). A major problem that was cited, is that despite years of research EGS is still not deployable as a commercial technology in the USA. Currently conventional and EGS technologies are stigmatized as being expensive, time intensive, and capital intensive with significant risk and little reward (GEOTH012; GEOTH018). Some were critical of the recent DOE "GeoVision" report that pushed EGS-geothermal as the solution to the USA's energy problem (GEOTH020). Others also highlighted that overblown promises in the past had damaged the industry, in reference to the MIT 2006 report, although the lack of progress is coupled with a lack of sustained policy, investment and innovation (GEOTH015). next 10 years and it may play a pivotal role in meeting the 2030 and 2050 GHG reduction targets. 
However, the industry needs to improve its marketing because given the timeline it takes to develop there is a risk that expensive alternatives will be deployed for example solar PV and battery storage, even in states like California where geothermal is currently deployed (GEOTH025). There is one limitation of existing conventional geothermal power, this is the fact that many of the best resources are not co-located with population centers or existing industry. Moreover, the average size of geothermal resources is too small to be of interest for the O\&G industry (GEOTH012, GEOTH018). Yet, the innovation within geothermal including low-temperature closed-loop and closed-loop conduction technologies, does give some hope for decoupling geographic restrictions and geothermal heat and power (GEOTH020; GEOTH032). There is considerable low-temperature geothermal (heat and power) potential in the USA, however this is hampered by the best locations being occupied by oil and gas operations and the post-life legal and contractual issues surrounding the redevelopment of orphaned oil and gas wells (GEOTH002; GEOTH004; GEOTH032).

One area where geothermal has remained underutilized is in the deployment of existing technologies that utilize geothermal heat, including both district energy systems and GSHP (GEOTH002; GEOTH003). This failure is largely linked to economies of scale and difficulties of retro-rifting into homes and businesses and the time it takes to be breakeven (GEOTH002; GEOTH003; GEOTH028). Why greater take-up of this technology has not occurred is clearly linked to a failure to market and educate and is partly linked to a bias for geothermal industries in the USA that dominantly focus on electricity production (GEOTH002).

Emerging innovations that could revolutionize the geothermal industry are because they enable larger scalable developments are the technologies that develop closed-loop conduction and lowtemperature heat and power projects. These innovative ideas allow for heat to be harvested for direct heat or power purpose (GEOTH012; GEOTH030; GEOTH032). GEOTH012 and GEOTH032 both indicated that closed-loop conduction at both low-temperature and supercritical temperatures enable geothermal technologies to access $80 \%$ of the USA. If these technologies can be demonstrated to be technologically and economically viable in the next 10 years, then they have the potential to revolutionize the power industry with or without the participation of the current O\&G or power industry. Successful development, however, requires simultaneous advances in legal frameworks, PR, marketing, education and technological developments (GEOTH032).

Existing geothermal technologies are technologically mature GSHP, district energy and conventional geothermal, they are unfortunately viewed externally as immature and high risk. Dramatic improvements in marketing, public relations and lobbying are needed. The industry needs to fight to 
530 re-insert itself into the minds of governments and decision makers, so that it is recognized as a low-

531 carbon and sustainable baseload. The industry needs to educate and manage all potential 532 stakeholders (individuals, companies, policy makers and regulatory bodies at the State and Federal 533 levels).

Presently the legal situation is relatively well understood with respect to conventional geothermal exploration and production. This understanding is linked to the production and re-injection of a fluid (water) in a geothermal reservoir. Despite this familiarity in states like California, the timelines for geothermal drilling permission remain prohibitively long (GEOTH025). New technological developments however, also highlight three pressing legal issues that need to be further developed and which impact the present and future geothermal industry.

541 The first of these is linked to the future exploration of heat. The legal blue-sky component of thermal exploration has not been properly considered, "who owns the heat?" (GEOTH032). New closed-loop supercritical thermal explorations are forcing the issue. GEOTH032 argued that if the oil and gas industry decides to flip the switch, and heat becomes their asset. Who owns the heat is a really important [future] question" (GEOTH032).

Secondly, as the number of depleted oil and gas fields and orphaned wells grow, these sites are potential future geothermal resource areas. However, until the legal framework is settled these potential resources will not be developed (GEOTH003; GEOTH032). The problem is, no geothermal developer would touch these wells without guarantee that it is not responsible for the environmental aspects relating to the former oil and gas activities. An example where the legislation is changing is

551 British Colombia, Canada (GEOTH003). The issues for geothermal development are the liability that 552 sits on capped wells "which is gigantic when it comes to methane emissions, and when it comes to 553 anything that can happen in the future regarding anything essentially (GEOTH003; GEOTH032). What 554 needs to happen is governments need to forgive any future liability may exist for those wells, then 555 there is a possibility that someone may investigate the possibility of redeveloping these fields into 556 geothermal reservoirs for direct heating or cooling or power purposes (GEOTH003; GEOTH012; 557 GEOTH022; GEOTH032). Unfortunately, there are also future liability issues which private entities 558 could introduce, such as induced earthquakes or subsidence linked to geothermal operations in the subsurface (GEOTH012; GEOTH027; GEOTH032) 
560 Thirdly, the redevelopment of abandoned mineral or coal mines, may carry similar legal issues, which 561 are also a future development opportunity for geothermal resources (GEOTH002). The development potential for abandoned mines therefore rests largely on a governmental desire to improve its energy stability and independence.

\subsubsection{Environmental}

565

The geothermal industry including the GRC, in the USA, does not successfully market or develop geothermal energy as a critical player in a low-carbon world (GEOTH025). The industry therefore, really needs to market the environmental benefits it brings. Geothermal heat and power can bring a baseload stability to the grid (GEOTHO02). Moreover, geothermal energy, across the board, can provide significant benefits to the environment providing low-carbon energy, it is renewable and it can be sustainable, if developed and managed properly (GEOTH002; GEOTH004; GEOTH014, GEOTH15; GEOTH027). Geothermal is also easy to decommission when compared to solar PV and wind which have significant environmental risk associated to their disposal (GEOTH012; GEOTH018). The industry therefore, needs to provide case studies publishing performance metrics; LCOE data, GHG emissions via Full Life Cycle Analyses (FCLA), and integrate this data into carbon abatement metrics to highlight potential energy savings, abatement costs and its impacts and benefits on grid stability and society.

Land use is also an important aspect of geothermal heat and power, geothermal uses the same or less in terms of land footprint as a nuclear plant does. Therefore, in terms of energy density or kilowatts per acre, geothermal is highly efficient, unlike wind or solar PV (GEOTH012; GEOTH029). In addition, the geothermal industry needs to celebrate the technological advances that allow it to mitigate all the environmental issues that have traditionally hampered the industry (GEOTH006; GEOTH012).

The industry however needs to develop standards in order to prevent conventional lower cost, or unconventional technologies from tarnishing its image, leading people to question its safety (GEOTH015). There is a perceived risk element with flash steam technologies, which can make them as polluting as coal power plants in limited end member scenarios. This occurs where the geothermal wells intersect hydrothermal resources in volcanic or carbonate rich reservoirs, for example in Turkey (GEOTH012; GEOTH015; GEOTH023). Generally speaking it should be noted that many flash steam development emissions are on the order of 75-150 kg (CO2)/MWh which is significantly lower than coal or gas power plants (GEOTH002). In relation to geological variability the geothermal industry needs to deliver a global code of business and standards regarding permissible GHG emissions, 
591 subsurface recommendations, skills required and standards for testing, observing, drilling and 592 engineering geothermal wells and building energy plants.

593 Another aspect that the geothermal industry needs to manage is its sub-surface image, how it impacts 594 drinking water reservoirs and how it uses water reserves. In theory it does not interfere with drinking 595 water supplies neither does it provide a drain on water resources, particularly in closed-loop 596 geothermal configurations. The industry also needs to manage the earthquake risk particularly linked 597 to its unconventional (EGS) and conventional development (GEOTH012; GEOTH018; GEOTH027; 598 GEOTH031).

599 Finally, and slightly tangential to the geothermal business, geothermal energy could be used in the 600 production of green-hydrogen, desalinated water or in the production of green diesel by using 601 geothermal heat to produce these products (GEOTH003; GEOTH012; GEOTH022; GEOTH028). 602 Integration of geothermal energy or power in the production of food for example could also bring 603 significant green benefits reducing the carbon intensity of many products, fuels and foods (GEOTH012; 604 GEOTH017).

\subsubsection{PESTLE-SUmmary:}

606

607

608

609

610

611

612

613

614

615

616

617

618

619

There are many different facets within the geothermal industry making it a complex industry to analyze. The external environment assessment provided by this PESTLE analysis reveals a challenging financial, regulatory, and operational environment for geothermal energy in the USA. In combination with marketing and stakeholder management, the question that needs to be answered in the next 510 years is: can geothermal technologies demonstrate commercial viability, baseload flexibility and emission abatement potential at an attractive cost for grid power and direct heat, compared to other renewable energies?

\subsection{DISCUSSION}

Exploratory research conducted here integrate the opinions of twenty geothermal and energy specialists via semi-structured interviews, with an analysis of low-carbon technology diversification activities of 36 energy companies. The analysis highlights several themes that will be discussed further below. 

LOW-CARBON ENERGY PORTFOLIO

622

623

624

625

626

627

628

629

630

631

633

634

635

636

637

638

639

640

641

642

643

644

645

646

647

648

649

650

Based on the discussions and results of this research, it is possible to ask the following questions: (i) Are we witnessing a dramatic shift in strategy of $O \& G$ companies? (ii) Is diversification leading to energy convergence between traditional power and $O \& G$ Industry? (iii) What is the role of geothermal in this diversification?

Results indicate that we are indeed witnessing a change in strategy of O\&G companies, moreover it is possible to make the sweeping statement that this change in strategy is dominantly restricted to European-based companies. US-based oil and gas companies appear not to be transitioning into renewable industries. This statement is backed up by the fact that recently public declarations by SHELL, BP, ENI, Equinor, TOTAL and Repsol, the six major European O\&G majors, have all proposed strategies to get to zero emissions by 2050 [7]. This diversification trend appears to be closely linked to ESG concerns and the link between fossil-fuels and global warming.

With respect to the provision of electricity a convergence trend is observed between the power, O\&G and ERP companies. The lines of commodity and utility company are blurring, particularly, as the O\&G companies are investing in non-fossil fuel technologies, that require them to produce and sell electricity. This observed energy convergence, will likely drive increasing competition within the decarbonization and electrification markets. To some extent this transition is largely occurring in Europe, rather than the USA, but its impacts will likely be felt globally. The Europe-US divide in strategy is intriguing. Recently IRENA [8], estimated Europe stands to make significant GDP, employment gains as a result of its progressive actions in transforming its energy mix. The driving factor appears to be a greater focus on national independence and self-sufficiency that is more urgent in the EU, whose petroleum reserves do not match those of the USA [6]. Using qualitative analysis another recent study [62] proposed a similar theory, arguing for a strong linkage between the oil majors' investing in renewables and the size of their proven reserves. Their analysis suggests that the US-majors do tend to have larger proven reserves at low breakeven oil prices [62]. Under the Trump (2016-2020) US-led administration, renewable strategies are lacking and are not currently being pursued at a Federal level. Although, this may change in the future, several democratic and even bipartisan proposals have been proposed which could have a progressive policy for example the Green New Deal [63], and the bipartisan alternative green deals which involve tax credits and zero percent interest loans, for geothermal energy development and investment in research [64]. 
651 In terms of geothermal strategy and geothermal diversification, the picture is less clear. Table 1a, indicated that geothermal technologies are part of the energy mix, however most of the geothermal activity is through geothermal development companies. Detailed analysis of the geothermal technology development (Table 2) reveals that not many companies are heavily invested in the technology despite its low-carbon baseload benefits. It is observed that EDF, ENEL and SHELL were more diversified than the "pure-play" geothermal companies. Although, that conclusion is limited by the omission of power produced and dollars spent on the technology, nonetheless it is startling to see how focused geothermal companies are within the geothermal industry, rather than developing integrated energy systems. Of the power companies that develop geothermal differences are observed, EDF operates the first commercial EGS plant in Soultz-sous-Forêts, France $[65,66]$. Whereas ENEL is involved in research and development of supercritical geothermal power via the DESCRAMBLE project [58]. At the lower temperature range ENGIE and The most diversified geothermal development and power company was ORMAT, with a focus on waste heat, and conventional geothermal power. Future research needs to focus on the amount of power produced to better rank the companies.

Regarding greenfield geothermal development and the power companies many US-based companies appear to have added geothermal power production through merger and acquisition activities rather than greenfield exploration and development. The O\&G companies that are publically involved in geothermal are SHELL and Equinor, which are European, but these projects remain in their demonstrator phase for the technologies. Both these companies have research and development activities in supercritical geothermal power, although SHELL's focus is on closed-loop conduction technologies whereas Equinor is focusing on EGS. It is possible that many are working privately behind the scenes because there are a number of consulting groups that offer geothermal consulting, for example, the Boston Consulting Group (BCG), LuxResearch, FutureBridge, and TGE Research. Whether other companies diversify into geothermal remains to be seen. Based on the 2018 end of year reports, it is clear that not all companies are developing strategies low carbon technologies and in particular geothermal. Future research should also extend this analysis qualitative analysis to the members of the Oil \& Gas Climate Initiative $(\mathrm{OGCl})$ to get qualitative metrics on investment levels and demonstration projects created per energy technology.

\section{2: BARRIERS TO GEOTHERMAL DEVELOPMENT IN THE OIL AND GAS INDUSTRY}

This study has identified many barriers to geothermal development across all scales of geothermal as shown in Table 5. The barriers are technical, commercial, marketing, legal, educational, stakeholder 
684 and deceptive competition from other technologies particularly gas, wind, solar PV, storage, biomass. 685 These results are in alignment with previous studies [67-72]. One factor not considered here but 686 raised by Kutschick, [70] was competitive reservoir utilizations (e.g. carbon sequestration and storage and nuclear waste). Young et al. [67] identified growing environmental and land-use restrictions impacting geothermal developments, For example:

(1) Land access,

(2) permitting,

(3) baseload set aside (including, baseload tax credit; baseload set-aside and VRE transmission charge), (4) the impact of Federal versus State incentives and (5) the cost of natural gas. The analysis presented here is largely qualitative, however the analysis of Young et al., [67] tried to analyze quantitatively the impact of improvements. Young et al., [67] also observed that high R\&D budgets in the USA correlated with the fastest growth in geothermal increase in terms of MW added.

When trying to understand whether O\&G companies will enter the geothermal industry the paradox is that many companies are already engaged in thermal applications of waste heat utilizing all the above ground technology that makes geothermal work. Therefore, why naturally occurring heat is not used in the earth to produce electricity remains unknown, rather than burning fossil fuels. However, the limited geographic scope, size, and environmental hazards of conventional geothermal developments, combined with the issues of profitability appear to have stigmatized the O\&G's industries view and therefore involvement in geothermal. This was reinforced by several interviewees during the interviews (GEOTH012; GEOTH020; GEOTH031; GEOTH032).

New geothermal innovations that detach geographic constraints, remove environmental issues, that are low-carbon and scalable may well change the future appetite of O\&G companies involvement in geothermal technologies. The closed-loop conduction is ironically born out of oil and gas technology, which may be applied to all temperature ranges. The new DOE funded project GEO at UT Austin [14, 15] was funded to get $O \& G$ companies closer to innovation in the geothermal industry. It is argued that the O\&G sector ought to pivot into geothermal technologies, because it leverages core competencies, IP, technology, assets, workforce and existing expertise; while meeting carbon neutrality commitments and portfolio diversification requirements.

Several interviewees commented that O\&G's involvement in geothermal could drop the cost of drilling from 20-40\% (GEOTH015; GEOTH032). Such claims are supported by the Equinor presentation which suggested learnings from the drilling of the IDDP wells in Iceland led to several identified improvements that could drop future drilling costs by $40 \%$ [73]. One example of how well the O\&G industry has innovated to lower cost is in Brazil, where the original sub-salt discovery well, Tupi, was drilled offshore Brazil, in 2006 by BG Group and cost US\$300 million [74]. Recently, the lowest cost 
717 (Lubetkin, R., pers. comm., November 2019). Welligence data analytics reveals that with experience 718 the drill days are reducing dramatically over the last 5 years (Lubetkin, R., pers. comm., November 719 2019). With reduced days drilling the costs have dropped by $\sim 80 \%$. If Geothermal companies could 720 innovate their drilling on a similar scale, perhaps they could reduce the costs geothermal exploration and development. Closed-loop conduction combined with and cheaper drilling and completion costs with could enable the co-location of thermal and power resources adjacent to population centers. With scalable and flexible low-carbon baseload assets on the horizon perhaps that would really be of interest to O\&G companies. A mutually beneficial relationship may be possible for the geothermal and O\&G industries.

\section{3: THE EXTERNAL ENVIRONMENT OF THE U.S. GEOTHERMAL INDUSTRY}

The interviews yielded key insights which highlight a difficult political environment in the USA for geothermal operators and the future of the industry, mainly dominated by a lack of a U.S. cohesive energy policy. Criticism of biased and dishonest government policies was present in many of the discussions relating to the geothermal industry which has placed geothermal at a disadvantage over solar PV and wind, particularly in California, (GEOTH002; GEOTH004). The exception to this are GSHP, which have perhaps the best tax/incentive situation of the geothermal technologies with the federal investment tax credit which was part of the Energy Policy Act of 2005, enabling up to $30 \%$ of the amount spent on purchasing and installing a geothermal heat pump system to be deducted from their federal income taxes [75]. However, the general lack of knowledge of this technology appears to have limited the overall adoption in the USA [76].

The results of the interviews and research conducted into the geothermal business essentially show five key general observations: (i) the industry is large, ranging from low temperature to supercritical conditions $\left(\sim 7^{\circ} \mathrm{C}\right.$ to $>350^{\circ} \mathrm{C}$ ), (ii) it is multi-faceted, and as the water cools it can be cascaded and reused by different industries who have different heat requirements, (iii) despite significant successes the industry is expensive with boutique or niche products, thus the view is that it is not always considered mature or viable by the general public and decision makers/governments, and (iv) it is largely unknown and $(v)$ it is stigmatized by issues that blighted its early development, even though these environmental risks have been mitigated. companies that develop geothermal and their relationships with the energy industry. The following observations are made (i) there are very few integrated geothermal companies, with companies 
749 specializing in niche geothermal areas; (ii) the industry appears not to be well integrated with other energy producers meaning that the developers of geothermal are independent and not integrated power companies: (iii) many O\&G and power companies are have not invested in geothermal even though they are comfortable with thermal industries such as waste-heat which utilizes the exact same technology. (iv) Power companies that own geothermal assets appear to have acquired these through merger and acquisition (M\&A) activities.

755

756

757

758

Within the USA, geothermal development is challenged and hampered by a longstanding tradition of cheap energy, and the policy bias that supported the growth of the wind, solar PV and gas to power. Even in areas where conventional geothermal is traditionally successful it is struggling to compete despite it providing flexible baseload power that fits in a low-carbon economy. Geothermal, at all scales also fights against the issues of climate denial in the USA. Critically, geothermal energy has declined to such an extent that it is not even featuring in debates about global warming and sustainability, which are dominated by wind, solar PV and storage or even CCUS $[77,78]$. The negative trends observed within this study are somewhat unique and they tend to go against the recent publications from the geothermal industry [79-81]. With respect to promoting geothermal, studies that over promote or rely one technology, e.g. EGS, [79-82], may be damaging to the industry,. If the experts interviewed are a gauge of industry opinion, then it seems existing US-DOE faith in EGS is misplaced. Geothermal needs a balanced promotion and it needs continued policy and funding.

However, negativity is not the only picture for geothermal. There are innovations occurring which could unlock geothermal technologies. If geothermal energy could be marketed better, stakeholders engaged and if costs reduced, then geothermal could compete. Recently, Ball [12] examined the LCOE and carbon abatement perspective of geothermal. It is clear from this analysis that the industry needs to underscore its place in the integrated low-carbon energy portfolio. If future predictions are correct, there are possibilities that low-temperature closed-loop, and closed-loop conduction and district heating geothermal technologies are highly competitive with or without a carbon price, if existing gas or coal are the abated fossil-fuels.

At the low-temperature end of the geothermal business studies for example Hamm, [79] or Lui et al. [83] argue for the massive benefits GSHP's can bring to the grid and to the country in terms of reducing the carbon footprint of heating and cooling. The story is similar for district heating, recent reports giving district heating a strong credibility $[84,85]$. But similarly these reports are failing to develop scenarios and mechanisms for integration and penetration into the USA's energy market. The lack of publically available data coupled with education and marketing gaps, are damaging for the long-term 
781

growth and stability of the geothermal industry. This requires urgent fixing because these largely matures technologies that could significantly help in the drive for decarbonization. Ball [12] recently studied the carbon abatement potential of geothermal highlighting that today certain matures technologies can challenge both existing coal and gas power providing significant long-term removal of carbon from the energy grid. Further work is needed however, to better define where in the USA geothermal can cost-effectively make these impacts. Ball [12] also highlighted that several emerging technologies could be cost effective, however it is not clear at the current development rates if geothermal can follow the experience and learning curves of wind and solar PV.

\subsection{CONCLUSIONS:}

This study has examined trends from within the energy industry to provide a snap-shot of the macroenvironment, activity and current trends in the industry, for the period 2018-2019. In addition this study utilized the views of twenty geothermal and energy specialists to understand the complexities that challenge the geothermal industry in a low-carbon portfolio.

Macro-scale insights reveal there is a significant split between European and US-based oil and gas companies in terms of strategy which is to a certain extent mirrored by the power companies. Presently, the oil and gas industry does not appear to be actively investing in baseload geothermal energy, favoring easy to deploy solar PV, onshore/offshore wind, biomass/gas, gas to power and storage. Diversification into low-carbon technologies is driving an energy convergence between the oil and gas and power sectors. Although energy diversification is occurring geothermal technologies are not currently a technology that companies are developing as part of their baseload low-carbon energy portfolio. Traditionally the oil and gas industry has avoided geothermal technologies because of technical/operational, commercial, legal and stakeholder barriers.

The geothermal sector is however replete with established and emerging technologies that enable its deployment in a variety of locations and scales. Yet, the geothermal industry in the USA and Europe remains largely a niche, pure-play industry. There are signals, however, that in the near future innovative geothermal energy technologies will play an increasingly important role in the low-carbon energy mix. With continued innovation geothermal has the potential to become a much more versatile energy source than is generally understood. Geothermal is not only useful for power, it can be utilized for heating or cooling, even flexible storage for example hybrid plants that combine geothermal and solar PV with thermal energy storage. There is considerable innovation within the geothermal industry, developing advanced geothermal concepts, for example, Eavor, GreenFire, 
813 CLIMEON, CLEAG. Furthermore, applications such as desalination, green hydrogen production and 814 lithium extraction from brines, increase the spectrum of products geothermal can deliver. Recent geothermal innovations that increase the footprint of scalable geothermal development might provide an avenue for the oil and gas industry to enter the geothermal domain. The advanced closedloop conduction and low temperature geothermal innovations that could unlock the concept of "geothermal anywhere". If technological and cost barriers can be overcome, oil and gas companies looking to develop low-carbon baseload heat and power, may see these new technologies align with their interests, in addition to leveraging their existing core competencies, IP, technology, assets, and workforce knowledge skills and experience.

\subsection{ACKNOWLEDGMENT}

The original work was completed as part of an MBA thesis at the London School of Business and Finance. I would like to acknowledge Dr. Allan Walker and Dr. Steve Priddy and the twenty anonymous interviewees for discussions relating to the completion of the original thesis, whose views greatly enriched the work.

\subsection{REFERENCES:}

830 [1] Roser, M., 2018, "Future Population Growth". OurWorldInData.org, online resource, accessed, 11/10/2019, https://ourworldindata.org/future-population-growth

832 [2] Kahan, A., 2019, "ElA projects nearly 50\% increase in world energy usage by 2050, led by growth 833 in Asia." EIA, online resource, accessed, 16/12/2019, 834 https://www.eia.gov/todayinenergy/detail.php?id=41433

835 [3] IPCC, 2007, "Climate Change 2007: Synthesis Report. Contribution of Working Groups I, II and III to 836 the Fourth Assessment Report of the Intergovernmental Panel on Climate Change" [Core Writing Team, 837 Pachauri, R.K and Reisinger, A. (eds.)]. IPCC, Geneva, Switzerland, 104 pp, online resource, accessed, 838 12/11/2019, https://www.ipcc.ch/report/ar4/syr/

839 [4] IPCC, 2018, "Summary for Policymakers. In: Global Warming of $1.5^{\circ} \mathrm{C}$. An IPCC Special Report on 840 the impacts of global warming of $1.5^{\circ} \mathrm{C}$ above pre-industrial levels and related global greenhouse gas 841 emission pathways, in the context of strengthening the global response to the threat of climate change, 842 sustainable development, and efforts to eradicate poverty" [Masson-Delmotte, V., Zhai, P., Pörtner, 843 H.-O., Roberts, D., Skea, J., Shukla, A., Pirani, P.R., Moufouma-Okia, W., Péan, C., Pidcock, R., Connors, 844 S., Matthews, J.B.R., Chen, Y., Zhou, X., Gomis, M.I., Lonnoy, E. Maycock, T., Tignor, M., and Waterfield, 845 T., (eds.)]. World Meteorological Organization, Geneva, Switzerland, 32 pp., online resource, accessed 846 10/11/2019, https://www.ipcc.ch/sr15/chapter/spm/

847 [5] USGCRP, 2018, "Impacts, Risks, and Adaptation in the United States: Fourth National Climate 848 Assessment," Volume II [Reidmiller, D.R., C.W. Avery, D.R. Easterling, K.E. Kunkel, K.L.M. Lewis, T.K. 849 Maycock, and B.C. Stewart (eds.)]. U.S. Global Change Research Program, Washington, DC, USA, 1515 850 pp., https://doi.org/10.7930/NCA4.2018 
851 [6] Elliott, E.D., 2013, "Why the U.S. Does Not Have a Renewable Energy Policy." Environmental Law

853 https://digitalcommons.law.yale.edu/cgi/viewcontent.cgi?article=6123\&context=fss papers

854 [7] Butler, N., 2020, "Look beyond European oil majors' steps to net zero." Financial Times, online 855 resource, accessed, 28/05/2020, https://www.ft.com/content/7571fadc-5889-11ea-abe5$856 \underline{8 \mathrm{e} 03987 \mathrm{~b} 7 \mathrm{~b} 20}$

857 [8] IRENA, 2020, “Global Renewables Outlook: Energy transformation 2050" (Edition: 2020), 858 International Renewable Energy Agency, Abu Dhabi. ISBN 978-92-9260-238-3, online resource, 859 accessed, 11/5/2020, https://www.irena.org/860 /media/Files/IRENA/Agency/Publication/2020/Apr/IRENA Global Renewables Outlook 2020.pdf

861 [9] Lazard, 2019, "Lazard's levelized cost of energy analysis, version 13.0," online resource, accessed, 862 20/12/2019, https://www.lazard.com/media/451086/lazards-levelized-cost-of-energy-version-130$863 \quad \underline{\text { vf.pdf }}$

864 [10] EIA, 2020, "Annual Energy Outlook 2020 with projections to 2050". U.S. Energy Information 865 Administration, online resource, accessed, 20/05/2020. 866 https://www.eia.gov/outlooks/aeo/pdf/AEO2020\%20Full\%20Report.pdf

867 [11] FCUC, 2019, "Global Trends in Renewable Energy Investment 2019," Frankfurt School-UNEP 868 Centre/BNEF, online resource, accessed,06/04/2020, http://www.fs-unep-centre.org (Frankfurt am 869 Main).

870 [12] Ball, P.J., 2020, "A review of geothermal technologies and their role in reducing greenhouse gas emission," J Energ Resour.

872 [13] Gillingham, K., and Huang, P., 2018, "Is abundant natural gas a bridge to a Low-carbon future or 873 a dead-end?" The Energy Journal, 40(2), pp.1-26, https://doi.org/10.5547/01956574.40.2.kgil

874 [14] Holden, 2019, 'Drilling for Clean Energy: New Initiative Positions Texas as Geothermal Energy 875 Leader.' UT-Austin, online resource, accessed, 04/12/2019, 876 https://news.utexas.edu/2019/12/04/drilling-for-clean-energy-new-initiative-positions-texas-as877 geothermal-energy-leader/

878 [15] Metcalfe, B., and Beard, J., 2019, "Innovations in deep geothermal wells could solve global energy 879 crisis within a decade" Houston Chronicle., online resource, accessed, 04/12/2019. https://www880 houstonchronicle-

881 com.cdn.ampproject.org/c/s/www.houstonchronicle.com/opinion/outlook/amp/Innovations-in882 deep-geothermal-wells-could-solve-14878075.php.

883 [16] Saunders, M., Lewis, P., and Thornhill, A., 2016, "Research methods for business students (seventh 884 edition)." Pearson Education UK, Prentice Hall, 768 pp.

885 [17] Purper, B., 2018, "The Forgotten Renewable: Geothermal Energy Production Heats Up." NPR 886 Radio, February 4th, 2018, online resource, accessed, 27/11/2019. 887 https://www.npr.org/2018/02/04/582132168/the-forgotten-renewable-geothermal-energy888 production-heats-up. 
889 [18] Saunders, M.N.K., 2012, "Choosing research participants", in G. Symons and C. Cassell (eds) The 890 Practice of Qualitative Organizational Research: Core Methods and Current Challenges. London: Sage, 891 pp. 37-55.

892 [19] BHE, 2019, "FORM 10-K. Berkshire Hathaway Energy." online resource, accessed, 01/10/2019. 893 https://www.brkenergy.com/

894 [20] Calpine, 2019, "Calpine, reports full year 2018 results." Calpine, online resource, accessed, 895 01/10/2019. www.calpine.com

896 [21] CLEAG, 2019, "CLEAG," online resource, accessed, 12/11/2019. https://www.cleag.energy/

897 [22] CLIMEON, 2019, “CLIMEON," online resource, accessed, 12/11/2019. https://climeon.com/

898 [23] EAVOR, 2019, “Closed Loop technology," online resource, accessed, 27/10/2019, 899 https://eavor.com/technology/

900 [24] GreenFire Energy, 2019, “GreenFire Energy," online resource, accessed, 11/10/2019 901 http://www.greenfireenergy.com

902 [25] Innergex, 2019, "Annual Report 2018," Innergex Renewable Energy Inc, online resource, accessed, 903 01/10/2019. https://www.innergex.com/

904 [26] JPower, 2019, "J-POWER Group Integrated Report," online resource, accessed, 01/10/2019, 905 http://www.jpower.co.jp/english/

906 [27] KenGen, 2019, "Integrated Annual Report and Financial Statemets," KenGen, online resource, 907 accessed, 01/10/2019, https://www.kengen.co.ke/.

908 [28] ORMAT, 2019, "2018 Annual Report." ORMAT Technologies, INC. pp244., online resource, 909 accessed, 11/10/2019, https://www.ormat.com/en/home/a/main/

910 [29] Razor, 2019, "Razor Energy, Corporate Presentation," September 2019, online resource, 911 accessed, 20/12/2019, https://www.razor-energy.com/

912 [30] Terra-Gen, 2019, "TerraGen," online resource, accessed, 11/10/2019, https://www.terra913 gen.com/

914 [31] DR, 2019, "2018 Summary Annual Report," Dominion Resources, 18 pp., online resource, 915 accessed, 11/10/2019, https://www.dominionenergy.com/

916 [32] DE, 2019, "2018 Annual Report and Form 10-K." Duke Energy, 284 pp., online resource, accessed, 917 11/10/2019, https://www.duke-energy.com/home

918 [33] EDF, 2019, "2018 Management Report, and Group Results," Électricité de France, 34 pp., online 919 resource, accessed, 11/10/2019, https://www.edfenergy.com/

920 [34] ENEL, 2019, "2018 Annual Report," ENEL, 551 pp., online resource, accessed, 11/10/2019, 921 https://www.enel.com/

922 [35] ENGIE, 2019, "2019 Integrated Report," ENGIE, 64 pp., online resource, accessed, 11/10/2019, 923 https://www.engie.com/en

924 [36] EXELON, 2019, "2018 Summary Annual Report," EXELON, 43 pp., online resource, accessed, 925 11/10/2019, https://www.engie.com/en, https://www.exeloncorp.com/ 
926 [37] Iberdrola, 2019, "2018 Integrated Report," Iberdrola, 10 pp., online resource, accessed, 927 11/10/2019, https://www.iberdrola.com/home

928 [38] NG, 2019, "2018 Annual Report and Accounts," National Grid, 248 pp., online resource, accessed, 929 11/10/2019, https://www.nationalgridus.com/Our-Company/

930 [39] NEXTERA, 2019, “Annual Report 2018," NEXTERA Energy, 140 pp., online resource, accessed, 931 11/10/2019, http://www.nexteraenergy.com/

932 [40] SC, 2019, "2018 Annual Report," Southern Company, 228 pp., online resource, accessed, 933 11/10/2019, https://www.southerncompany.com/

934 [41] EON, 2019, "2018 Annual Report." E.ON, 256 pp., online resource, accessed, 11/10/2019, 935 https://www.eon.com/en.html

936 [42] Ørsted, 2019, “Annual report 2018," Ørsted, 193 pp., online resource, accessed, 11/10/2019, 937 https://orsted.com/en

938 [43] OXY, 2019, "2018 Annual Report," Occidental Petroleum Corporation, 112 pp., online resource, 939 accessed, 11/10/2019, https://www.oxy.com/Pages/default.aspx

940 [44] BP, 2019, "2018 Annual Report," BP, 294 pp., online resource, accessed, 11/10/2019 941 https://www.bp.com/.

942 [45] Chevron, 2019, "2018 Annual Report," Chevron, 92 pp., online resource, accessed, 11/10/2019, 943 www.chevron.com/

944 [46] CNR, 2019, "2018 Annual Report," Canadian Natural Recourses, 118 pp.. online resource, 945 accessed, 11/10/2019, https://www.cnrl.com/

946 [47] COP, 2019, "2018 Annual Report," ConocoPhillips, 196 pp., online resource, accessed, 947 11/10/2019, http://www.conocophillips.com/

948 [48] Devon, 2019, "Devon Energy Sustainability Report," Devon Energy, 76 pp., online resource, 949 accessed, 11/10/2019, http://www.devonenergy.com/

950 [49] ENI, 2019, “2018 Annual Report." ENI, 96 pp., online resource, accessed, 11/10/2019, 951 https://www.eni.com/en IT/home.page

952 [50] Equinor, 2019, "2018 Annual Report," Equinor, online resource, accessed, 11/10/2019, 953 https://www.equinor.com/en.html

954 [51] Shell, 2019, "2018 Annual Report," Shell, 228 pp., online resource, accessed, 11/10/2019, 955 https://www.shell.com/.

956 [52] Suncor, 2019, "2018 Annual Report," Suncor Energy Inc., 158 pp., online resource, accessed, 957 11/10/2019, https://www.suncor.com/en-ca

958 [53] TOTAL, (2019). 2018 Annual Report. TOTAL, p. 388. online resource accessed 11/10/2019, 959 http://www.Total.com/en.

960 [54] ExxonMobil, 2019, "2018 Summary Annual Report," ExxonMobil, 52 pp., online resource, 961 accessed, 11/10/2019, https://corporate.exxonmobil.com/ 
[55] ReportLinker, 2019, "Top 20 Geothermal Power Companies 2019," ReportLinker.com, online resource, accessed, 11/11/2019, https://www.reportlinker.com/p05779281/Top-20-GeothermalPower-Companies.html?utm source=PRN

[56] Walton, J., 2019, "World's top 10 utility companies," Investopedia, online resource accessed 1608-2019, https://www.investopedia.com/articles/investing/022516/worlds-top-10-utilitycompanies.asp.

[57] Forbes, 2016, "The world's biggest public energy companies 2016". Forbes, online, resource accessed, 16-08-2019, https://www.forbes.com/pictures/hefj45fim/introduction/\#7bcaf14a1624

[58] Bertani, R., Büsing, H., Buske, S., Dini, A., Hjelstuen, M., Luchini, M., Manzella, A., Nybo, R., Rabbel, W., Serniotti, L., and the DESCRAMBLE Science and Technology Team, 2018, "The First Results of the DESCRAMBLE Project." Proceedings, 43rd Workshop on Geothermal Reservoir Engineering Stanford University, Stanford, California, February 12-14, SGP-TR- 213, https://pangea.stanford.edu/ERE/pdf/IGAstandard/SGW/2018/Bertani.pdf

[59] Friðleifsson, G.Ó., Elders, W.A., Zierenberg, R.A., Fowler, A.P.G., Weisenberger, T.N., Mesfin, K.G., Sigurðsson, O., Níelsson, S., Einarsson, G., Óskarsson, F., Guðnason, E.A., Tulinius, H., Hokstad, K., Benoit, G., Nonog, F., Loggia, D., Parat, F., Cichy, S.B., Escobedo, D., Mainprice, D., 2020, "The Iceland Deep Drilling Project at Reykjanes: Drilling into the root zone of a black smoker analogue." Journal of Volcanology and Geothermal Research, 391, https://doi.org/10.1016/j.jvolgeores.2018.08.013

[60] NVIVO, 2020, NVIVO qualitative data analysis software, QSR International, online resource accessed, 07, 20, 2020, https://www.qsrinternational.com/nvivo-qualitative-data-analysissoftware/about/nvivo

[61] Porter, M. E., 1985, "The Competitive Advantage: Creating and Sustaining Superior Performance," NY: Free Press, 592 pp. https://www.hbs.edu/faculty/Pages/item.aspx?num=193

[62] Pickl, M.J., 2019, The renewable energy strategies of oil majors - From oil to energy?, Energy Strategy Reviews, 26, https://doi.org/10.1016/j.esr.2019.100370

[63] OtherLab, 2019, "The Green New Deal: The enormous opportunity in shooting for the moon. OtherLab.com," online resource, accessed, 21/12/2019, https://www.otherlab.com/blog-posts/thegreen-new-deal-the-enormous-opportunity-in-shooting-for-the-moon

[64] Rao, V., and Cook, L., 2020, "Drilling for Geothermal Energy is a green new deal for both sides of the aisle," Houston Cronicle, online resource, accessed, 29/05/2020 https://www.houstonchronicle.com/opinion/outlook/article/Opinion-Drilling-for-geothermalenergy-is-a-15301660.php

[65] Vidal, J., Genter, A., and Schmittbuhl, J., 2016, "Pre-and post-stimulation characterization of geothermal well GRT-1, Rittershoffen, France: insight form acoustic image logs of hard fractured rock," Geophysics Journal International, 206(2), pp., 845-860, https://doi.org/10.1093/gji/ggw181

[66] Baujard, C., Genter, A., Dalmais, E., Maurer, V., Hehn, R., Rosillette Vidal, J., and Schmittbuhl, J., 2017, "Hydrothermal characterization of wells GRT-1 and GRT-2 in Rittershoffen, France Implications on the understanding of natural flow systems in the Rhine graben," Geothermics, 65, 255-268.

[67] Young, K.; Levine, A.; Cook, J.; Heimiller, D.; Ho, J., 2019, GeoVision Analysis Supporting Task Force Report: Barriers-An Analysis of Non-Technical Barriers to Geothermal Deployment and Potential 
Improvement Scenarios. Golden, CO: National Renewable Energy Laboratory. NREL/PR-6A20-71641. https://www.nrel.gov/docs/fy19osti/71641.pdf.

1004 [68] Bierman, S. L., Stover, D. F., Nelson, D. F., and Lamont, W. J., 1977, "Innovation versus Monopoly: 1005 Geothermal Energy in the West," U.S. Department of Energy (USA), DGE/3036-1, 898 pp. 1006 https://www.osti.gov/biblio/6632437

1007 [69] Lund, J.W., and Bloomquist, R.G., 2012, "Development of geothermal policy in the United States 1008 - what works and what doesn't work," Proceedings, Thirty-Seventh Workshop on Geothermal 1009 Reservoir Engineering, Stanford University, Stanford, California, January 30 - February 1, 2012, SGP1010 TR-194, https://pangea.stanford.edu/ERE/pdf/IGAstandard/SGW/2012/Lund.pdf

1011 [70] Kutschick, 2013, "Barriers to the use of geothermal energy," online resource, accessed, 1012 20/12/2019, http://www.geoelec.eu/wp-content/uploads/2013/07/GEOELEC-Regulatory1013 Barriers_Kutschick_Pisa.pdf.

1014 [71] Matek, B., 2015, "What Is Really Keeping Geothermal Power Back?” OilPrice.com, online resource, 1015 accessed, 20/12/2019, https://oilprice.com/Alternative-Energy/Geothermal-Energy/What-Is-Really1016 Keeping-Geothermal-Power-Back.html

1017 [72] Lenders, E., 2018, "Renewable energy potential in Texas and business opportunities for the 1018 Netherlands, Commissioned by the ministry of Foreign Affairs, 64 pp., online report, accessed 1019 01/12/2019. https://www.rvo.nl/sites/default/files/2018/01/renewable-energy-potential-in-

\section{0 texas.pdf}

[73] Sørlie, C., 2018, "Deep geothermal energy for power production new opportunities for O\&G industry?" CGER, online resource, accessed, 11/12/2019, http://cger.no/doc//pdf/NPF\%20presentation,\%2007.03.2018.pdf.

1024 [74] OT, 2019, Tupi Oil Field, Brazil, Offshore Technology, online resource, accessed, 11/12/2019, https://www.offshore-technology.com/projects/tupi-oilfield/

1026 [75] EIA, (2019). Levelized Cost and Levelized Avoided Cost of New Generation Resources AEO2019. 1027 U.S. Energy Information Administration, Online resource, accessed, 01/12/2019. 1028 https://www.eia.gov/outlooks/aeo/assumptions/pdf

1029 [76] Letcher, T.M., 2019, "Managing Global Warming: An Interface of Technology and Human Issues," 1030 Elsevier, Academic Press. 820 pp.

1031 [77] Diringer, E., Townsend, B., Bobeck, J., Huber, K., Leung, J., Meyer, N., Vine, N., Ye, J., and Grosman, 1032 D., 2019," Getting to Zero: A U.S. climate agenda," C2ES, Climate Innovation 2050. 66 pp.,

1034 [78] IRENA, 2019, "Renewable Power Generation Costs in 2018," International Renewable Energy 1035 Agency, Abu Dhabi, pp 88., ISBN 978-92-9260-126-3, https://www.irena.org/1036 /media/Files/IRENA/Agency/Publication/2019/May/IRENA Renewable-Power-Generations-Costs-in1037 2018.pdf

1038 [79] Hamm, S., 2019, "GeoVision: Harnessing the power beneath our feet," U.S. Department of Energy, 1039218 pp., online resource, accessed, 30/09/3019, http://www.osti.gov/scitech

1040 [80] Dumas, P., Garabetian, T., Serrano, C., and Pinzuti, V., 2019, "EGEC Geothermal Market Report 10412018 (Summary)," European Geothermal Energy Council, 20 pp., online resource, accessed, 1042 10/11/2019, https://www.egec.org/media-publications/egec-geothermal-market-report-2018/ 
1043 [81] Augustine, C.; Ho, J.; and Blair, N., 2019, "GeoVision Analysis Supporting Task Force Report: 1044 Electric Sector Potential to Penetration," NREL/TP-6A20-71833. Golden, CO: National Renewable 1045 Energy Laboratory, online resource, accessed, 30/09/3019, 1046 https://www.nrel.gov/docs/fy19osti/71833.pdf.

1047 [82] MIT, 2006, "The Future of Geothermal Energy Impact of Enhanced Geothermal Systems (EGS) on 1048 the United States in the 21st Century," An assessment by an MIT-Led interdisciplinary panel. 1049 Massachusetts Institute of Technology, 372 pp., online resource, accessed, 04/12/2019, 1050 https://energy.mit.edu/wp-content/uploads/2006/11/MITEI-The-Future-of-Geothermal-Energy.pdf

1051 [83] Liu, X., Hughes, P. McCabe, K., Spitler, J., and Southard, L., 2019, "GeoVision Analysis Supporting 1052 Task Force Report: Thermal Applications-Geothermal Heat Pumps," ORNL/TM-2019/502. Oak Ridge, 1053 Tennessee: Oak Ridge National Laboratory, online resource, accessed, 05/28/ 2019, 1054 https://info.ornl.gov/sites/publications/Files/Pub103860.pdf.

1055 [84] Tredinnick, S., 2013, "Why Is District Energy Not More Prevalent in the U.S.? HPAC.com, online 1056 resource, accessed, 02/12/2019, https://www.hpac.com/heating/why-district-energy-not-more1057 prevalent-us

1058 [85] DOE, 2019, "Energy Efficiency and Energy Security Benefits of District Energy, Report to Congress, 1059 July 2019," U.S. Department of Energy, online resource, accessed, 03/12/2019, 1060 https://www.districtenergy.org/blogs/district-energy/2019/09/26/doe-issues 

during the interview depending on the requests prior to the interview.

\title{
Interview Questions
}

3 sections: structured, open questions, more specific (interviewer biased) depending on the open questions

\section{Structured} \\ How experienced in Geothermal are you? \\ Is your experience technical/sector /economic/ management \\ Dominant experience base (EU, USA, Other) \\ If US-based where in the USA (California or Texas or?) \\ Explerience in Geothermal - Academia, Startup, Established, E\&P company or Power company?
}

\section{Open Queistons/ Discussion Topics}

Historically, why do you think geothermal has not made a bigger penetration?

What do you make of the comment by Bierman et al 1977 (pg 227/571) that Power and Oil and Gas companies deliberately ran a monopoly on resrouces and controlled the best agreage?

Do you think geothermal will play a role in the future low carbon energy mix?

What are the biggest rivals to geothermal energy in a low carbon world?

EIA 2019 published a MW value of geothermal of 39 USD. This is by far the cheapest of all energies even without subsidies?

Why is it Power and oil and gas companies have not adopted geothermal energy?

Do you think geothermal can or should market itself better with Power and E\&P companies?

Should depleted fields be re-developed as a geothermal resource?

How willing are corporate stakeholders in key industrial sectors to engage in geothermal low carbon energy solutions?

I observe that Power companies are more integrated than E\&P. But why are E\&P not taking geothermal when they are optimally placed? Why this contradiction?

What are the biggest challenges to re-integrating Geothermal into the existing energy system/housing stock?

One of the obstacles I hear is geothermal is not efficient for electricity produciton, but I was amazed when studying CPH - Gas Turbines are only $50 \%$ efficient! Why this bias?

What are the key industrial sectors that would most benefit from the uptake of geothermal energy generation solutions? How would you recommend improvements to increase optimal take up of geothermal low carbon energy solutions in today's wider energy mix?

Are the existing financial incentives to corporations seeking to pursue low-carbon energy production strategies at state, federal and international levels suitable?

Do you think carbon tax should be introduced over subsidies?

What structural (energy/policy) changes are needed?

Why is it so hard to get PPA for geothermal energy?

How can we change the mindeset of the value of geothermal?

Regarding the modelling of geothermal energy production, in the wider context of low carbon energy solutions should heat and electicity be valued the same?

How would you estimate the value of heat? Vs Electicity?

IF risk is seen as a limiting factor for geothermal what do you think closed loop or EGS will do to this perception? I have seen $\mathrm{CO} 2$ proposed as a conductor of heat in closed loop, why is it the industry has not used $\mathrm{H} 2$ ?

Im amazed at the maturity of HEAT technology. Why do you think geothermal is not as widely accepted or known? $\mathrm{CPH}$ is an accepted technology, why do you think there is more opposition towards geothermal? Heating/Cooling is about $50 \%$ of energy demand. Equates to $39 \%$ of GHG emissions - why is thermal not used more?

\section{Additional Insights}

On a different scale geothermal Heat-pumps how can companies/govermnents increase uptake? (e.g. Solar now interest free and leasing) 